\title{
Will We Ever Have Paris? \\ Canada's Climate Change Policy AND FEDERALISM 3.0
}

\author{
JASON MACLEAN ${ }^{*}$
}

\begin{abstract}
Global climate change is at the point where politics as usual is not sufficient to combat it. The author argues that a new conceptualization of constitutionalism and federalism will be required to respond to this change. What the author calls federalism 3.0 will be a bottom-up approach to politics, where individuals are empowered by governments and institutions to shape climate policy. This bottom-up approach is encapsulated in the Paris Climate Change Agreement. Canadian Prime Minister Justin Trudeau has publicly declared Canada's commitment to climate leadership through mobilizing all elements of Canadian society. However, the author argues Trudeau's policies to date are merely an example of formalistic, check-the-box constitutionalism, rather than substantive, federalism 3.0.
\end{abstract}

\section{TABLE OF CONTENTS}

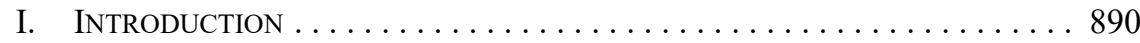

II. The Paris Climate Change Agreement $\ldots \ldots \ldots \ldots \ldots \ldots \ldots . \ldots 93$

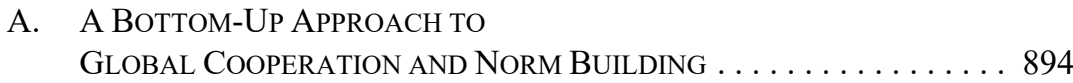

B. CANADA AND the "High Ambition CoALition" . . . . . . . . . 897

C. Mind THE AMBITION GAP! . . . . . . . . . . . . . . . . . . 898

III. Canadian Climate Change Policy and Federalism 1.0

- Passing THe BUCK ......................... 900

A. The Constitutional Controversy
That Wasn't (And Still Isn't) $\ldots \ldots \ldots \ldots \ldots \ldots \ldots \ldots . \ldots 1$

B. FEDERALISM 2.0: COOPERATION AND HARMONIZATION, OR STILl PAsSing THE Buck? . . . . . . . . . . . . . . . . . . 903

C. WhateVER HAPPENED TO THE FEDERAL Sustainable DEVELOPMENT ACt? . . . . . . . . . . 907

IV. Canadian Climate Change Policy and Federalism 3.0

— From Retrenchment to Restoring CanAdians' TRUST . . . . . . . 909

A. CANADA's ThiRd National Policy, OR LET'S TALK TV? . . . . . . . . . . . . . . . . . . . 910

B. Let's TAlk Climate Action,

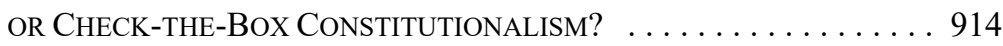

V. Conclusion: The "Deliverology” of Paris, or PiPelines? . . . . . . 931 
Does the power to change the world belong to the people in the conference rooms of Le Bourget or to the people in the streets of Paris? ${ }^{1}$

\section{INTRODUCTION}

We have entered a "new era of climate reality." 2 In 2015, the global average concentration of carbon dioxide $\left(\mathrm{CO}_{2}\right)$ in the atmosphere reached the "symbolic and significant milestone of 400 parts per million" (ppm). ${ }^{3}$ According to data collected by the World Meteorological Organization, the atmospheric $\mathrm{CO}_{2}$ concentration reached 400 ppm again in 2016, the Earth's hottest year on record, ${ }^{4}$ and will likely remain at that level "for many generations." this development in perspective, the citizens' environmental organization 350.org takes its name from the research of renowned climate scientist James Hansen, who argued in 2008 that humanity should aim to cap the concentration of $\mathrm{CO}_{2}$ in the atmosphere at $350 \mathrm{ppm}$ in order to avoid dangerous and irreversible climate tipping points, which are further associated with a $2^{\circ} \mathrm{C}$ increase in global temperature above pre-industrial levels. ${ }^{6}$

Avoiding the most dangerous and disruptive impacts of climate change will require, rather than business as usual, a rather unusual law and politics. Above all, meeting the challenges posed by the new climate reality will require fulfilling, not merely the formal and procedural requirements of the law, ${ }^{7}$ but also the law's deepest substantive aspirations, its underlying normative foundations. Constitutions, after all, "are not just about restraining and limiting power; they are about the empowerment of ordinary people in a democracy and allowing them to control the sources of law and harness the apparatus of government to their legitimate aspirations." Democracy "is committed to the idea and practice that governance is to be for the people and, as important, by the people. This deceptively simple but actually subversive and sophisticated notion provides a starting point for any discussion of governance in all its forms." Indeed, as former US President Barack Obama recently remarked in his farewell address, the "Constitution is a remarkable, beautiful gift. But it's really just a piece of parchment. It has no power on its own. We, the people, give it power.

(18 November 2015), online: $<$ https://harpers.org archive/2015/12/power-in-paris/>.

World Meteorological Organization, "Globally Averaged CO2 Levels Reach 400 parts per million in 2015" (24 October 2016), online: <https://public.wmo.int/en/media/press-release/globally-averaged-co2levels-reach-400-parts-million-2015>.

3 Ibid.

4 Jugal K Patel, “How 2016 Became Earth's Hottest Year on Record,” The New York Times (18 January 2017), online: <https://www.nytimes.com/interactive/2017/01/18/science/earth/2016-hottest-year-onrecord.html>.

$5 \quad$ World Meteorological Organization, supra note 2.

6 James Hansen et al, "Target Atmospheric $\mathrm{CO}_{2}$ : Where Should Humanity Aim?" (2008) 2 Open Atmospheric Science J 217 [Hansen et al, "Target atmospheric $\mathrm{CO}_{2}$ "]. See also online: $<\mathrm{https} / / 350$. org/>.

$7 \quad$ See e.g. Jason MacLean, "Autonomy in the Anthropocene? Libertarianism, Liberalism, and the Legal Theory of Environmental Regulation" (2017) 40:1 Dal LJ 279 [MacLean, "Autonomy in the Anthropocene?'].

8 Jeremy Waldron, Political Political Theory: Essays on Institutions (Cambridge, Mass: Harvard University Press, 2016) at 43. See also Heather K Gerken, “A New Progressive Federalism” (2012) 24 Democracy: J Ideas 37.

$9 \quad$ Allan C Hutchinson, The Companies We Keep: Corporate Governance for a Democratic Society (Toronto: Irwin Law, 2005) at 35 [emphasis in original]. 
We, the people, give it meaning - with our participation, and with the choices that we make and the alliances that we forge." 10

How is this subversive and sophisticated conception of constitutionalism actually accomplished? Jeremy Waldron puts it this way:

\begin{abstract}
In general, we need to understand the importance of the way in which a constitution provides housing for the political activity of a society, establishing an in-between of furniture and formality so that public deliberation becomes a structured enterprise, allowing the views of one person to be brought articulately into relation with the views of others and facilitating the formation of well-thought-through, responsible, and politically effective opinions. $^{11}$
\end{abstract}

For Waldron, this conception of constitutional culture as "affirmative empowerment"12 means that the state must provide both the institutional fora and the information its citizens need in order to meaningfully — that is, equally and effectively — participate in public governance. Ideals are not enough; progressive constitutionalism must also attend to the design and dimensions of institutions capable of enabling citizen engagement in democratic governance. $^{13}$

This, to be sure, is not "your father's federalism."14 As Heather Gerken argues in respect of the not-unrelated practice of American federalism, "when you really look at how federalism works in practice, it looks not like anything you see in the case law. Our model of federalism is what you read in a case. But when federalism plays out, it's messy and it's not easy to trace." 15 Aspirational, "progressive" federalism, Gerken argues, is driven by its "participatory dimensions." ${ }^{\prime \prime}$ It includes, on this at once progressive and practical view of federalism "all the way down," not only the federal government and the states, but also "the substate, local, and sublocal institutions that constitute states: juries, zoning commissions, local school boards, locally elected prosecutor's offices, state administrative agencies, and the like." ${ }^{17}$ Climate change policy, the topic at the heart of this article, is a case in point. Once again remarking on the American experience to date, Gerken observes that "[p]rogressives have long leveraged local population concentrations into political power. Indeed, much of the most important work on progressive issues started at the local level. Take climate change: From green building codes to cap-and-trade, the bulk of the work ... is being accomplished outside of Washington." 18

Similarly in the Canadian context, the abrogation of responsibility for environmental protection and sustainable development at the federal level — which is described in greater detail later in this article — has galvanized some provinces, municipalities, Indigenous

"President Obama's Farewell Address: Full Video and Text," The New York Times (10 January 2017), online: $<$ https://www.nytimes.com/2017/01/10/us/politics/obama-farewell-address-speech.html?_r=0>. Waldron, supra note 8 at 36.

Ibid.

Ibid at 7.

Heather K Gerken, “The Loyal Opposition” (2014) 123:6 Yale LJ 1958 at 1963.

Michael Jonas, "Progressive Politics From the Ground Up," CommonWealth (Summer 2017) 56 at 64. Ibid.

Heather K Gerken, "Federalism as the New Nationalism: An Overview” (2014) 123:6 Yale LJ 1889 at 1910. See also Heather K Gerken, "The Supreme Court 2009 Term - Foreword: Federalism All the Way Down" (2010) 124:4 Harv L Rev 6 at 21.

Gerken, "A New Progressive Federalism," supra note 8 at 48. 
communities, and civil society organizations to move in and try to fill the void. ${ }^{19}$ While such efforts are to be lauded, they cannot hope to succeed on their own absent federal facilitation. Our new climate reality calls for a new conception of constitutionalism - call it federalism 3.0 - capable of encouraging and empowering Canadians to participate equally alongside their elected representatives amid the surrounding sources of social and economic power in collaboratively fashioning collective commitments to a sustainable future.

Taking its cue from the emerging legal scholarship on progressive federalism touched on above, the argument advanced here is unapologetically aspirational insofar as it attempts to articulate a normatively attractive account of the potential of existing institutional arrangements and recent public policy pronouncements. Pace the conventional expectations of students and scholars of federalism, however, this necessarily means going beyond the text of the Constitution itself in order to excavate its popular foundations and envisage their potential fulfillment. After all, if the participatory dimensions of federalism 3.0 are nowhere to be found in the text of the Constitution Act, 1867 (whether in its division of powers provisions or elsewhere), neither is the likewise unwritten principle of democracy. Nor, for that matter, is the principle of democracy — let alone its actual practice — confined to representation, suffrage, or the processes of government. Democracy, rather, is "connected to substantive goals, most importantly, the promotion of self-government." ${ }^{20}$ As Mari Matsuda argues, either we will become deeply aspirational in our constitutional interpretation, or we will face other challenges. ${ }^{21}$

The argument advanced here is also unapologetically critical. As one anonymous peer reviewer of this article remarked, "I have no objection to wishful thinking or to pure theory, but no-one should complain when fact and theory do not coincide. They rarely do. And this author does." 22 Indeed, I do. Citizens of constitutional democracies should care - and complain - when the facts on the ground do not live up to the shared principles and commitments that we choose to live up to, namely, our collective working theory of a constitutional democracy. The success and ultimate survival of our polity depends on it. The alternative - corrosive, self-defeating cynicism - is hardly an attractive one, no matter how hard-won it may appear.

The specific argument advanced in this article unfolds as follows. Part II discusses the simultaneously ambitious and aspirational bottom-up architecture of the United Nations Framework Convention on Climate Change (UNFCCC) agreement concluded in Paris in December 2015 and its implications for Canada's climate governance, particularly the need for greater citizen engagement in climate-related decision-making. Part III briefly retraces the regrettable history of Canadian climate and sustainable development policy through the

19 See e.g. Jason MacLean, Meinhard Doelle \& Chris Tollefson, "The Past, Present, and Future of Canadian Environmental Law: A Critical Dialogue" (2015-2016) 1:1 Lakehead LJ 79 at 83.

20 Reference re Secession of Quebec, [1998] 2 SCR 217 at para 64. See also Switzman v Elbling, [1957] SCR 285 at 302; Rv Oakes, [1986] 1 SCR 103 (identifying as a democratic value the "faith in social and political institutions which enhance the participation of individuals and groups in society" at 136). Mari Matsuda, "The Next Dada Utopian Visioning Peace Orchestra: Constitutional Theory and the Aspirational”" (2017) 62:4 McGill LJ 1203.

I am grateful to the peer reviewer for making this objection to my approach so pointedly, thereby forcing me to sharpen my argument and commit fully and openly to its aspirational valence at the very outset of the analysis. I cannot help but note, however, that it is this very kind of constructively critical dialogue and debate that is the very lifeblood of a vital constitutional democracy, and also the kind of dialogue and debate that the state ought to facilitate to fulfill its constitutional obligations. 
conventional lens of federalism and the question of jurisdiction over environmental protection, ranging from the federal government's penchant for passing the buck to the provinces (federalism 1.0) to so-called federal-provincial cooperation, harmonization, and further federal retrenchment (federalism 2.0). Part IV argues that a new conception of aspirational federalism (federalism 3.0) capable of meeting Canada's climate change commitments is urgently needed. This Part articulates and applies this conception of federalism to Canada's recent promises of greater citizen engagement, including a new, nation-to-nation relationship with Indigenous peoples, and its initial but potentially path dependent climate policies and decisions taken during the early days of the post-Paris era. At a minimum, federalism 3.0 must take the shape of new institutions that provide Canadians with the opportunities and the information they need to have a meaningful voice in articulating the shape and substance of Canada's climate change policies. This article concludes, however, that Canada's policy commitments and initial climate-governance decisions - the facts on the ground - are instead the result of a kind of formalistic, "checkthe-box constitutionalism," and fall far short of fulfilling the aspirations of both the historic Paris Agreement and the promise of a new constitutional law and politics in Canada. Instead of true democracy, we are issued "Deliverology"; instead of Paris, we are promised pipelines. Unless we immediately change course, the harm to both our constitutional culture and our climate may well be irreparable.

\section{The Paris Climate Change Agreement}

The Paris climate change negotiations conducted pursuant to the $\mathrm{UNFCCC}^{23}$ brought together over 36,000 participants, including approximately 23,100 government officials, 9,400 representatives from UN bodies and agencies, intergovernmental and civil society organizations, and some 3,700 members of the media. ${ }^{24}$ The agreements ${ }^{25}$ concluded in Paris $^{2}$ establish a new international climate change regime that includes all countries and seeks to address climate change mitigation, adaptation, loss and damage, finance, technology transfer, and capacity building. ${ }^{26}$ As discussed below, the Paris Agreement represents an ambitious, bottom-up approach to global cooperation and norm building in response to our new climate reality. ${ }^{27}$

23 Intergovernmental Negotiating Committee for a Framework Convention on Climate Change, Annex I to the Report of the Committee; United Nations Framework Convention on Climate Change, UNFCCC, 5th Sess, 2nd Part, UN Doc A/Ac.237/AddI (1992), online: <https://unfccc.int/resource/docs/a/18p 2a01.pdf $>$.

$24 \quad$ See Jennifer Allan et al, "Summary of the Paris Climate Change Conference: 29 November - 13 December 2015" (December 2015) 12:663 Earth Negotiations Bulletin, online: <enb.iisd.org/download/ pdf/enb12663e.pdf>.

25 The phrase "Paris Agreement" is used throughout this article to refer collectively to the Paris Conference of the Parties (COP) Decision (Report of the Conference of the Parties on its twenty-first session, held in Paris from 30 November to 13 December 2015, 29 January 2016, Dec 1/CP.21, CP, $21 \mathrm{st}$ Sess, UN Doc FCCC/CP/2015/Add.1 [Paris COP Decision]) and the Paris Agreement; the latter was adopted in Paris as an Annex to the Paris COP Decision, but it became a separate, legally binding agreement when ratified by at least 55 parties accounting for at least an estimated 55 percent of total global GHG emissions. See Paris Agreement, being an Annex to the Report of the Conference of the Parties on its twenty-first session, held in Paris from 30 November to 13 December 2015 - Addendum Part two: Action taken by the Conference of the Parties at its twenty-first session, 29 January 2016, Dec 1/CP.21, CP, 21 st Sess, UN Doc FCCC/CP/2015/10/Add.1 ["Paris Agreement"] at 21-36, online: <https://unfccc. int/resource/docs/2015/cop21/eng/10a01.pdf>.

26 Allan et al, "Summary of the Paris Climate Change Conference," supra note 24 at 13-18.

27 See Meinhard Doelle, "The Paris Agreement: Historic Breakthrough or High Stakes Experiment?" (2016) 6:1 \& 2 Climate Law 1 [Doelle, "The Paris Agreement"]. 


\section{A. A BOTTOM-UP APPROACH TO GLOBAL COOPERATION AND NORM BUILDING}

The Paris Agreement completes a decade-long transition from a top-down, legally binding climate change regime focused on the mitigation of developed countries' greenhouse gas (GHG) emissions to a bottom-up, substantively non-binding approach aimed at fostering global cooperation through transparency, peer pressure, and voluntary norm building. ${ }^{28}$ In particular, the Paris Agreement represents a radical change in direction from the Kyoto Protocol, which was based on legally-binding GHG reduction targets with enforceable consequences for non-compliance. ${ }^{29}$ While the Kyoto Protocol enjoyed some success in Europe, the United States refused to ratify it, ${ }^{30}$ and Canada chose to withdraw from the protocol rather than genuinely attempt to meet its GHG emission reduction target. ${ }^{31}$ Moreover, most developed countries outside of Europe have declined to accept a second commitment-period target pursuant to the 2012 Doha Amendments to the protocol. ${ }^{32}$ Meanwhile, GHG emissions in a number of developing countries - including China, India, Brazil, and South Africa - have continued to increase significantly. ${ }^{33}$ Accordingly, the Paris negotiations attempted to establish a fundamentally different approach, one that moves from a "top-down strategy to a bottom-up approach." 34

The bottom-up approach of the Paris Agreement is based on the idea that voluntary, selfimposed commitments are more likely to result in compliance than are "targets and timetables" ${ }^{35}$ imposed by the global community and implemented by top-down, national mandates accompanied by government support for clean energy technologies. ${ }^{36}$ The Paris Agreement seeks to build, from the bottom-up, new norms of state behaviour through the clear articulation of an ambitious collective goal, interaction and information-sharing among states and other actors, responsiveness to scientific evidence and changing circumstances,

28 Ibid.

See Meinhard Doelle, From Hot Air to Action: Climate Change, Compliance and the Future of International Environmental Law (Toronto: Thomson, 2005).

30 Report of the Conference of the Parties on its Third Session, Kyoto Protocol to the UN Framework Convention on Climate Change, 3rd Sess, pt 2, Annex I, Agenda Item 5, UN Doc FCCC/CP/1997/L.7/add. 1 (1997), reprinted in 37 ILM 22 (1998).

31 Canada was the first country to withdraw from Kyoto: Environment and Climate Change Canada, "A Climate Change Plan for the Purposes of the Kyoto Protocol Implementation Act 2012: Canada's Withdrawal from the Kyoto Protocol," (19 June 2013), online: <https:/www.ec.gc.ca/Publications/ default.asp?lang=En\&n=EE4F06AE-1\&xml=EE4F06AE-13EF-453B-B633-FCB3BAECEB4F $>$; see also Doelle, "The Paris Agreement," supra note 27.

32 Doha Amendment to the Kyoto Protocol, (8 December 2012) at Ch xxvii 7 c, online: $<$ https://treaties.un. org/pages/ViewDetails.aspx? src=TREATY\&mtdsg no=XXVII-7-c\&chapter=27\&lang=en $>$.

33 For data on countries' GHG emissions, see Climate Action Tracker, online: <www.climateaction tracker.org $>$. While Kyoto included only developed countries, the Paris Agreement includes both developed and developing countries.

34 Daniel C Esty, "Bottom-Up Climate Fix," The New York Times (21 September 2014), online: <www.nytimes.com/2014/09/22/opinion/bottom-up-climate-fix.html? r=0>; see also David A Wirth, "The International and Domestic Law of Climate Change: A Binding International Agreement Without the Senate or Congress?" (2015) 39:2 Harv Envtl L Rev 515 at 521; Cinnamon P Carlarne, "Rethinking a Failing Framework: Adaptation and Institutional Rebirth for the Global Climate Change Regime" (2012) 25:1 Geo Intl Envtl L Rev 1 at 2-3; William Boyd, "Climate Change, Fragmentation, and the Challenges of Global Environmental Law: Elements of a Post-Copenhagen Assemblage” (2010) 32:2 U Pa J Intl L 457 at 457; David Roberts, "The Conceptual Breakthrough Behind the Paris Climate Treaty" VOX (15 December 2015), online: <http://www.vox.com/2015/12/15/10172238/paris-climatetreaty-conceptual-breakthrough>.

Esty, ibid.

Ibid; Doelle, "The Paris Agreement," supra note 27. 
and transparency and informal accountability mechanisms designed to ratchet up countries' efforts. $^{37}$

How does the Paris Agreement address each of these objectives? The Agreement begins by articulating a highly ambitious collective goal. Article 2 of the Agreement encourages parties to hold "the increase in the global average temperature to well below $2{ }^{\circ} \mathrm{C}$ above preindustrial levels" and pursue "efforts to limit the temperature increase to $1.5^{\circ} \mathrm{C}$ above preindustrial levels, recognizing that this would significantly reduce the risks and impacts of climate change." ${ }^{38}$ Article 2 establishes the expectation that the Agreement's long-term ambition will be matched by the individual and coordinated actions of the parties. ${ }^{39}$ Accordingly, $1.5^{\circ} \mathrm{C}$ is now the ultimate standard against which the success of collective, global climate change mitigation efforts will be judged. ${ }^{40}$ Whereas the Agreement lacks a top-down mechanism for the assessment and enforcement of countries' individual contributions to this collective goal, the Agreement instead requires parties to publicly justify the level of their mitigation efforts vis-à-vis the Agreement's long-term ambition over time. ${ }^{41}$

The baseline for countries' mitigation efforts pursuant to the Paris Agreement is established by the nationally-determined contributions (NDCs) filed along with parties' ratification of the Agreement; the Intended Nationally Determined Contributions (INDCs) filed by most countries in advance of the Paris negotiations will serve as the default NDCs unless strengthened through domestic processes prior to ratification, ${ }^{42}$ through the Agreement's initial global stocktaking exercise scheduled for $2018,{ }^{43}$ or on the voluntary initiative of a party. ${ }^{44}$

In addition to the progressive ratcheting-up of parties' mitigation efforts relative to their baseline NDCs, article 4.1 of the Paris Agreement stipulates that parties will collectively aim to reach a global peaking of GHG emissions "as soon as possible." 45 Again, true to its bottom-up architecture, the Paris Agreement does not dictate how parties must meet or measure the adequacy of their NDCs. Instead, article 4.1 proceeds to explain that parties are expected to undertake rapid reductions in GHG emissions "in accordance with best available science, so as to achieve a balance between anthropogenic emissions by sources and removals by sinks of greenhouse gases in the second half of this century, on the basis of equity, and in the context of sustainable development and efforts to eradicate poverty." 46

Allan et al, supra note 24; Doelle, "The Paris Agreement," ibid; Daniel Bodansky, "The Paris Climate Change Agreement: A New Hope?” (2016) 110:2 AJIL 288.

Paris Agreement, supra note 25, art 2.

Ibid.

Doelle, "The Paris Agreement," supra note 27 at 8.

See Paris COP Decision, supra note 25 at para 27.

See e.g. Susana Mas \& Catherine Cullen, "Justin Trudeau Signs Paris Climate Treaty at UN, Vows to Harness Renewable Energy," CBC (22 April 2016), online: <www.cbc.ca/news/politics/paris-agreementtrudeau-sign-1.3547822>; but see Laura Payton, "Liberals Back Away From Setting Tougher Carbon Targets," CTV News (18 September 2016), online: <https://web.archive.org/web/20170811111521/ http://www.ctvnews.ca/politics/liberals-back-away-from-setting-tougher-carbon-targets-1.3075857>. Paris COP Decision, supra note 25 at para 20.

Paris Agreement, supra note 25, art 4.11.

Ibid, art 4.1.

Ibid. 
Article 4.2 extends and further shapes the individualized obligation expressed in articles 2 and 4.1 by providing that "[e]ach party shall prepare, communicate and maintain successive nationally determined contributions that it intends to achieve. Parties shall pursue domestic mitigation measures, with the aim of achieving the objectives of such contributions." ${ }^{, 47}$ This disclosure, transparency, and accountability mechanism applicable to all parties under the Agreement embodies US Supreme Court Justice Louis Brandeis's canonical insight that sunlight is the "best of disinfectants." 48 The assumption undergirding this mechanism is that peer pressure and more general public pressure can be just as effective as a formally binding, top-down legal obligation in driving compliance. ${ }^{49}$ Perhaps more so, at the international level.

Because the language of the Paris Agreement is technologically neutral, however, the Agreement leaves to individual countries — and possibly multilateral initiatives ${ }^{50}$ — the determination of how best to pursue domestic mitigation of GHG emissions in a manner that promotes integrated solutions and maximizes sustainability ${ }^{51}$ while minimizing risks, ${ }^{52}$ for example the loss of energy security. ${ }^{53}$

In order to ensure that this voluntary, state-driven process proceeds apace, article 14 establishes the critically important iterative approach of the Paris Agreement, whereby parties gather together every five years to take stock of collective progress and table progressively more ambitious GHG emissions reduction targets for the next five-year period. ${ }^{54}$ This "global stocktake" is designed to "inform Parties in updating and enhancing, in a nationally determined manner, their actions and support in accordance with the relevant provisions of this Agreement, as well as in enhancing international cooperation for climate action." ${ }^{55}$ Complementing this "ratcheting" mechanism as a means of driving progressively more ambitious domestic efforts in a kind of "race to the top," article 4.19 states that all

47 Ibid, art 4.2. See also article 13, which sets out a number of other procedural obligations designed to facilitate transparency regarding parties' domestic mitigation efforts (and others, including adaptation efforts and efforts directed at financial, technology transfer and capacity-building support provided to developing countries - important as these efforts are, they are beyond the scope of this article). Louis D Brandeis, Other People's Money and How the Bankers Use It (New York: Frederick A Stokes, 1914) at 92.

49 This assumption has long been debated in the literature on so-called soft law. See e.g. Dinah Shelton, ed, Commitment and Compliance: The Role of Non-Binding Norms in the International Legal System (New York: Oxford University Press, 2000); David G Victor, Kal Raustiala \& Eugene B Skolnikoff, eds, The Implementation and Effectiveness of International Environmental Commitments: Theory and Practice (Cambridge, Mass: MIT Press, 1998). For a more up-to-date discussion of the pros and cons of different regulatory approaches, see Chris Tollefson, Anthony R Zito \& Fred Gale, "Symposium Overview: Conceptualizing New Governance Arrangements" (2012) 90:1 Public Administration 3.

50 See e.g. Paris Agreement, supra note 25, art 6.2, which recognizes that parties may engage in cooperative approaches to achieve their domestic NDCs, including the use of internationally transferred mitigation outcomes, which could include emissions trading schemes and other institutions capable of linking national climate policies.

51 See ibid, art 6.4, which establishes a new mechanism to "contribute to the mitigation of greenhouse gas emissions and support sustainable development."

52 See Meinhard Doelle, "Integration Among Global Environmental Regimes: Lessons Learned From Climate Change Mitigation" in Aldo Chircop, Ted L McDorman \& Susan J Rolston, eds, The Future of Ocean Regime-Building: Essays in Tribute to Douglas M. Johnston (Leiden, Netherlands: Martinus Nijhoff Publishers, 2009) 63.

53 See e.g. Liam Wagner et al, "Trading Off Global Fuel Supply, $\mathrm{CO}_{2}$ Emissions and Sustainable Development" (2016) 11:3 PLoS ONE.

54 See Paris COP Decision, supra note 25 at paras 20, 23; Paris Agreement, supra note 25, art 14 (see also arts 4.2, 4.9).

55 Paris Agreement, ibid, art 14.3 [emphasis added]. 
parties "should strive to formulate and communicate long-term low greenhouse gas emission development strategies." ${ }^{\circ 6}$

\section{B. CANADA AND THE "High AMbition CoAlition"}

It is entirely too early to assess the Paris Agreement. Nevertheless, upon its conclusion the Agreement was instantly pronounced "historic,", a "landmark," 58 the "world's greatest diplomatic success," "59 "a watershed deal aimed at preventing catastrophic climate change," the "beginning of the end of fossil fuel era," ${ }^{\prime 61}$ and, not least, kind of a "big, big deal."62

The remarkable optimism surrounding the Paris Agreement is due in large part to the failed negotiations that preceded it, particularly the failure of COP 15 in Copenhagen in 2009, which ended in acrimony, bitter disappointment, and profound pessimism about the prospects of a multilateral climate change framework. ${ }^{63}$ Following years of doubt and indecision, the Paris Agreement appears to have restored faith in the ability of multilateralism to effectively address problems besetting the international community. ${ }^{64} \mathrm{But}$ it is perhaps the high ambition of the Agreement itself that most accounts for the high hopes engendered in Paris in 2015.

The Agreement's high ambition was not, however, an inevitable outcome of the negotiations, as the dismal failure of COP 15 in Copenhagen illustrates. Rather, the high ambition of the Paris Agreement began on the margins of the formal meetings organized by the French Presidency. ${ }^{65}$ Side meetings were instigated by the Marshall Islands and included

Ibid, art 4.19.

Joby Warrick \& Chris Mooney, "196 Countries Approve Historic Climate Agreement," The Washington Post (12 December 2015), online: <https:/www.washingtonpost.com/news/energy-environment/wp/ 2015/12/12/proposed-historic-climate-pact-nears-final-vote/>.

Coral Davenport, "Nations Approve Landmark Climate Accord in Paris," The New York Times (12 December 2015), online: <https://www.nytimes.com/2015/12/13/world/europe/climate-change-accordparis. html? $\mathrm{r}=0>$.

Fiona Harvey, "Paris Climate Change Agreement: The World's Greatest Diplomatic Success," The Guardian (14 December 2015), online: < https://www.theguardian.com/environment/2015/dec/13/parisclimate-deal-cop-diplomacy-developing-united-nations $>$.

Eric Reguly \& Shawn McCarthy, "Paris Climate Accord Marks Shift Toward Low-Carbon Economy," The Globe and Mail (12 December 2015), online: <https://www.theglobeandmail.com/news/world/ optimism-in-paris-as-final-draft-of-global-climate-deal-tabled/article27739122/>.

Union of Concerned Scientists, "Global Action on Historic Climate Change Agreement Expected in Paris" (12 December 2015), online: <https://www.ucsusa.org/news/press_release/global-action-onhistoric-climate-change-agreement-expected-in-paris-0651>. See also Ann̄e-Marie Codur, William Moomaw \& Jonathan Harris, “After Paris: The New Landscape for Climate Policy” (February 2016) Global Development and Environment Institute, Tufts University, Climate Policy Brief No 2 at 1, online: <www.ase.tufts.edu/gdae/Pubs/climate/ClimatePolicyBrief2.pdf $>$.

Thomas L Friedman, "Paris Climate Accord is a Big, Big Deal," The New York Times (16 December 2015), online: <https://www.nytimes.com/2015/12/16/opinion/paris-climate-accord-is-a-big-big-deal. html $>$. But see Allan et al, supra note 24 at 44 noting that many observers immediately dismissed the Paris Agreement as "business as usual."

See e.g. Meinhard Doelle, "The Legacy of the Climate Talks in Copenhagen: Hopenhagen or Brokenhagen?" (2010) 4:1 Carbon \& Climate L Rev 86; Daniel Bodansky, "The Copenhagen Climate Change Conference: A Postmortem" (2010) 104:2 AJIL 230.

Allan et al, supra note 24 at 45; see also Jason MacLean, "The Misleading Promise of 'Balance' in Canada's Climate Change Policy," Policy Options (29 March 2016), online: <policyoptions.irpp.org/ magazines/march-2016/the-misleading-promise-of-balance-in-canadas-climate-change-policy/> [MacLean, "The Misleading Promise of "Balance"']. Allan et al, ibid at 44. 
15 "like-minded" ministers from different regions, including Canada. ${ }^{66}$ "These informal [parallel] meetings formed the basis of what became known as the 'High Ambition Coalition." "67 Canada's Minister of the Environment and Climate Change, Catherine McKenna, explained that "Canada has advocated for this recognition of the urgency of the threat to small-island states, like the Marshall Islands with whom we now stand as part of the High Ambition Coalition.... The Coalition brings together developed and developing countries from around the world as we lay the groundwork for a safe climate future." 68

This initially loose alliance eventually came to comprise up to 100 countries that agreed on a list of "ambitious asks," including a clear long-term goal (the $1.5^{\circ} \mathrm{C}$ target) and the fiveyear review cycle (the global stocktaking mechanism). ${ }^{69}$ As the previous section sought to illustrate, these "ambitious asks" were ultimately included in and constitute the core of the Paris Agreement. ${ }^{70}$ Several commentators have described the transparency and global stocktake mechanisms as the Agreement's "mechanisms for ambition.",71

Realizing these "ambitious asks," however, will almost assuredly prove far more difficult than setting them. As a multilateral instrument, success will depend largely on what happens next at the national, subnational, and regional levels. ${ }^{72}$ Particularly important will be how subnational efforts feed into and drive national efforts. This article will explore the implications of this crucial question for Canada's climate change policy in Part III below. Before proceeding, however, the ambition of the Paris Agreement must be further examined in respect of its explicit "ambition gap.","73

\section{Mind the Ambition Gap!}

A remarkable feature of the Paris COP Decision is its explicit acknowledgement of its own ambition gap. The Paris COP Decision "[n]otes with concern that the estimated aggregate greenhouse gas emissions levels in 2025 and 2030 resulting from the intended nationally determined contributions do not fall within the least-cost $2{ }^{\circ} \mathrm{C}$ scenarios but rather lead to a projected level of 55 gigatonnes in 2030." ${ }^{, 74}$ The Paris COP Decision further notes "that much greater emission reduction efforts will be required than those associated with the intended nationally determined contributions in order to hold the increase in the global average temperature to below $2{ }^{\circ} \mathrm{C}$ above pre-industrial levels." 75 Specifically, GHG emissions must be reduced to 40 gigatonnes in order to meet the Paris Agreement's

Karl Mathiesen \& Fiona Harvey, "Climate Coalition Breaks Cover in Paris to Push for Binding and Ambitious Deal," The Guardian (8 December 2015), online: <https:/www.theguardian.com/environ ment/2015/dec/08/coalition-paris-push-for-binding-ambitious-climate-change-deal $>$; Carol Linnitt, "Canada Joins 'High Ambition Coalition' To Push for Strong Climate Treaty in Paris," The Narwhal (11 December 2015), online: $<$ https://thenarwhal.ca/canada-joins-high-ambition-coalition-push-strongclimate-treaty-paris> [Linnitt, "Canada Joins 'High Ambition Coalition"'].

Allan et al, supra note 24 at 44.

Linnitt, "Canada Joins 'High Ambition Coalition,"” supra note 66.

Allan et al, supra note 24 at 44.

See also ibid.

Ibid.

Doelle, "The Paris Agreement," supra note 27 at 20. For a further discussion of this point in respect of multilateral environmental governance, see Jason MacLean, "Troubled Waters: Reinvigorating Great Lakes Environmental Governance through Deliberative Democracy" (2018) Sea Grant L \& Policy J [forthcoming].

Doelle, "The Paris Agreement," ibid at 10.

Paris COP Decision, supra note 25 at para 17 [emphasis original]

Ibid. 
ambitious collective target. ${ }^{76}$ The "ambition gap" quantified in the COP Decision is thus fifteen gigatonnes by 2030. Another way of expressing the Agreement's "ambition gap" is to observe that the set of INDCs filed at or before the conclusion of the Paris Agreement, which represented 95 percent of global GHG emissions, "put collective efforts only on a path to an approximately $3^{\circ} \mathrm{C}$ temperature increase." 77 That is a full degree higher than the Paris Agreement's upper target of $2^{\circ} \mathrm{C}$, which Hansen and his colleagues nonetheless consider to be "dangerous." 78

A mere eight months following the conclusion of the COP Decision and the Paris Agreement, a number of climate scientists warned that we were already alarmingly close to reaching and surpassing the lower $1.5^{\circ} \mathrm{C}$ temperature target. ${ }^{79}$ Data collected by NASA and the US National Oceanic and Atmospheric Association (NOAA) demonstrated that the first six months of 2016 were the hottest on record, averaging $1.3^{\circ} \mathrm{C}$ above the pre-industrial average ${ }^{80}$ August 2016 was, as of this writing, the hottest of any month since the advent of adequate recording in $1880,{ }^{81}$ making the month of August 2016 the eleventh consecutive record-breaking month for global temperatures, ${ }^{82}$ the longest such streak since $1880 .{ }^{83}$ According to NASA climate scientist Gavin Schmidt, "I certainly would not say that we have now gotten to that initial Paris number and are going to stay there.... But I think it's fair to say that we are dancing with that lower target." 84

In order to mind and ultimately close the "ambition gap" between the initial GHG reduction commitments (INDCs) made by the parties and the Agreement's overall objective, "[s]ubstantial enhancement or over-delivery on current INDCs by additional national, subnational and non-state actions is required to maintain a reasonable chance of meeting the

$76 \quad$ Ibid.

77 Allan et al, supra note 24 at 44. See also Joeri Rogelj et al, "Paris Agreement Climate Proposals Need a Boost to Keep Warming Well Below $2^{\circ} \mathrm{C}$ " (2016) 534 Nature 631.

78 James Hansen et al, "Ice Melt, Sea Level Rise and Superstorms: Evidence From Paleoclimate Data, Climate Modeling, and Modern Observations that $2^{\circ} \mathrm{C}$ Global Warming Could Be Dangerous" (2016) 16:6 Atmospheric Chemistry \& Physics 3761 (arguing that even " $2{ }^{\circ} \mathrm{C}$ global warming is dangerous" and concluding that "we have a global emergency. Fossil fuel $\mathrm{CO}_{2}$ emissions should be reduced as rapidly as practical" at 3801) [Hansen et al, "Ice Melt, Sea Level Rise and Superstorms"].

79 See e.g. Robin McKie, "Scientists Warn World Will Miss Key Climate Target," The Guardian (6 August 2016), online: <https://www.theguardian.com/science/2016/aug/06/global-warming-target-missscientists-warn>.

80 Henry Fountain, "Global Temperatures Are on a Course for Another Record This Year," The New York Times (19 July 2016), online: <https://www.nytimes.com/2016/07/20/science/nasa-global-temperatures2016.html> [Fountain, "Global Temperatures"].

81 National Aeronautics and Space Administration, "GISTEMP Update: NASA Analysis Finds August 2016 Another Record Month,” (12 September 2016), online: < https://data.giss.nasa.gov/gistemp/news/ $20160912 />$. See also Henry Fountain, "How Hot Was It in July? Hotter Than Ever," The New York Times (22 August 2016), online: <https:/www.nytimes.com/2016/08/23/science/how-hot-was-it-in-julyhotter-than-ever.html>.

82 National Aeronautics and Space Administration, ibid.

83 Michael Slezak, "Hottest Ever June Marks 14th Month of Record-Breaking Temperatures," The Guardian (20 July 2016), online: <https:/www.theguardian.com/environment/2016/jul/20/june-201614th-consecutive-month-of-record-breaking-heat-says-us-agencies>.

84 Fountain, "Global Temperatures," supra note 80 [emphasis added]. See also Hansen et al, "Ice Melt, Sea Level Rise and Superstorms," supra note 78. For a similar analysis sounding a similar warning, see Katarzyna B Tokarska et al, "The Climate Response to Five Trillion Tonnes of Carbon" (2016) 6 Nature Climate Change 851 at $854-55$ [citations omitted]:

Our results also show that five trillion tonnes of cumulative carbon emissions, corresponding approximately to the unregulated exploitation of the fossil fuel resource, would result in considerably larger global and regional climate changes than previously suggested. Such climate changes, if realized, would have extremely profound impacts on ecosystems, human health, agriculture, economies and other sectors. 
target of keeping warming well below 2 degrees Celsius." 85 This burden will — and ought - to be disproportionately onerous for developed country parties such as Canada. As article 4.4 of the Paris Agreement states, "[d] eveloped country Parties should continue taking the lead by undertaking economy-wide absolute emission reduction targets. $"{ }^{\circ 6}$ The reputational stakes for Canada are particularly high. Canada was a highly visible and outspoken member of the "High Ambition Coalition" during the Paris Agreement negotiations, and Prime Minister Justin Trudeau, on signing the Agreement at the UN in April 2016, remarked that "[t] oday, with my signature, I give you our word that Canada's efforts will not cease.... Climate change will test our intelligence, our compassion and our will. But we are equal to that challenge." 87

Are we? Is Canada capable of doing its part to close the "ambition gap" inherent in the Paris Agreement? This is the question pursued throughout the remainder of this article. Part III below examines the federal government's "pass the buck" approach to environmental protection generally - call it environmental federalism 1.0. Part III then proceeds to examine the short-lived and largely unfulfilled promise of an upgrade to environmental federalism 2.0 characterized by attempts at "cooperative federalism" and "harmonization." This analysis sets the stage for Part IV, which argues that a new model of environmental federalism and national policymaking more generally — call it federalism 3.0 - will be required if Canada is to create a climate change policy capable of meeting its ambitious commitments under the Paris Agreement.

\section{Canadian Climate Change Policy ANd Federalism 1.0 - PASsing The BuCK}

Neither the "environment" nor "climate change" is mentioned in the Constitution Act, 1867. ${ }^{88}$ As Justice LaForest explained in Friends of the Oldman River Society v. Canada (Minister of Transport), "the Constitution Act, 1867 has not assigned the matter of 'environment' sui generis to either the provinces or Parliament. The environment, as understood in its generic sense, encompasses the physical, economic and social environment touching several of the heads of power assigned to the respective levels of government. $" 89$ Justice LaForest proceeded to characterize the environment as "a constitutionally abstruse matter which does not comfortably fit within the existing division of powers without considerable overlap and uncertainty." ${ }^{, 90}$ More recently, Allan Hutchinson has characterized climate change as a "constitutional puzzle." 91 Underlying the formation of a credible and cooperative national climate change policy involving the federal, territorial, and provincial governments, Hutchinson argues, is the "hidden dynamic" of the "constitutional division of

Rogelj, supra note 77 at 631.

Paris Agreement, supra note 25, art 4.4.

Quoted in Mas \& Cullen, supra note 42.

(UK), 30 \& 31 Vict, c 3, ss 91(10), 91(12), reprinted in RSC 1985, Appendix II, No 5.

[1992] 1 SCR 3 at 63.

Ibid at 64 .

Allan Hutchinson, "Climate Change: A Constitutional Puzzle," The Globe and Mail (27 April 2016), online: $<$ https://www.theglobeandmail.com/opinion//climate-change-a-constitutional-puzzle/article297 64807/> [Hutchinson, "Climate Change"]. 
powers. Who can do what? And who can prevent the other from doing what?"92 While "the question of which jurisdiction has constitutional authority to regulate what aspects of climate and GHG emissions in the Canadian federation is not an easy one," whether politically or legally, ${ }^{93}$ on closer inspection it becomes clear that it is not - or it need not be - a controversial one.

\section{A. The Constitutional Controversy THAT WASN'T (AND STILL ISN'T)}

The jurisdictional controversy over the environment and climate change in Canada is an example par excellence of the principle plus ça change, plus c'est la même chose. As ShiLing Hsu and Robin Elliot recount, former Alberta Premier Peter Lougheed once warned of a "major constitutional battle" over the regulation of GHG emissions. ${ }^{94}$ Most recently, it was former Saskatchewan Premier Brad Wall sounding the constitutional alarm. In response to the federal government's public statements about the importance of establishing a "strong price on carbon right across the country" as part of a pan-Canadian climate change policy, ${ }^{95}$ Premier Wall stated that "[w]e would constitutionally challenge any attempt by a federal government to impose a tax on, for example, a government Crown (corporation) like SaskPower or SaskEnergy. This does not come into play with the private sector, but it does with respect to government entities, we believe. And we would challenge it." ${ }^{, 96}$ And so it goes.

In her comprehensive and up-to-date analysis of the constitutional jurisdiction to regulate GHG emissions in Canada, Nathalie Chalifour notes that considerable ink has already been

92 Ibid. Authority to legislate on environmental issues is shared in Canada. The federal government may legislate pursuant to its powers over fisheries, navigation and shipping, trade, international borders, offshore coastal areas, federal lands, criminal law, taxation, and, notably, the Peace, Order, and Good Government (POGG) power; provincial governments may legislate pursuant to their powers over property and civil rights, "local matters," provincial land, and natural resources, among others. See Constitution Act, 1867, supra note 88, ss 91-92.

93 Nathalie Chalifour, "Canadian Climate Federalism: Parliament's Ample Constitutional Authority to Legislate GHG Emissions through Regulations, a National Cap and Trade Program, or a National Carbon Tax" (2016) University of Ottawa Faculty of Law Working Paper No 2016-18 at 2-3, online: $<$ https:// papers.ssrn.com/sol3/papers.cfm?abstract_id=2775370 $>$ [Chalifour, "Climate Federalism"]. Peter Lougheed, "Address" (delivered to the Canadian Bar Association, Calgary, 14 August 2007) [unpublished], cited in Shi-Ling Hsu \& Robin Elliot, "Regulating Greenhouse Gases in Canada: Constitutional and Policy Dimensions” (2009) 54:3 McGill LJ 463 at 465.

$95 \quad$ Kathleen Harris, "Justin Trudeau Won't Rule Out Imposing Carbon Price Plan on Provinces," CBC News (20 July 2016), online: <www.cbc.ca/news/politics/trudeau-carbon-tax-provinces-1.3686769>. Cited in Andy Blatchford, "Baloney Meter: Brad Wall Could Challenge any Federal Carbon Tax on Crown Corps," CBC News (28 July 2016), online: <www.cbc.ca/news/politics/baloney-meter-brad-wallcarbon-tax-1.3699134>. Premier Wall also (and perhaps more importantly) opposed a carbon tax on economic grounds: see Ian Vandaelle, "Brad Wall Slams Ottawa for Mulling Carbon Tax: 'Now is Not the Time," Business News Network (14 June 2016), online: <https://web.archive.org/web/20160615 111950/http://www.bnn.ca/News/2016/6/14/Brad-Wall-Dissonant-to-even-talk-carbon-tax.aspx>; Shawn McCarthy, "Saskatchewan Premier Brad Wall Rejects Ottawa's Carbon Pricing Plan," The Globe and Mail (18 February 2016), online: <https://www.theglobeandmail.com/news/politics/saskatchewanpremier-brad-wall-rejects-ottawas-carbon-pricing-plan/article28808667/>. In addition, both Saskatchewan and Nova Scotia oppose the federal government's stated intention to accelerate the phaseout of coal-fired power plants. See Shawn McCarthy, "Provinces Balk at Federal Push to Accelerate Phasing-Out of Coal Power," The Globe and Mail (2 September 2016), online: <www.theglobeand mail.com/report-on-business/industry-news/energy-and-resources/provinces-balk-at-federal-push-toaccelerate-phasing-out-of-coal-power/article31685245/>. 
spilled on this issue. ${ }^{97}$ A review of this literature reveals a variety of technical, doctrinal disagreements over which constitutional head of power is the preferable basis for the exercise of federal jurisdiction - for example, the "national concern" doctrine under POGG versus POGG's "emergency doctrine"; or the taxation power versus the criminal law power versus the declaratory power.

These doctrinal disputes notwithstanding, there is an emerging consensus that the federal government has broad powers to enact legislation in respect of the environment generally, and climate change in particular. Hsu and Elliot argue that "the Canadian constitution does not present any significant barriers to federal or provincial regulation"98 and that policy considerations strongly favour the use of a federal carbon tax to regulate GHG emissions along with the use of the Canadian Environmental Assessment Act (in its pre-2012 iteration) to review proposed economic activities that may increase GHG emissions. ${ }^{99}$ Chalifour concludes "there is ample authority within the Constitution for a strong federal role in regulating GHG emissions and pricing carbon without displacing appropriately scoped provincial climate programs." ${ }^{100}$ Hutchinson observes that the federal government has legally valid — if politically contentious — avenues available to it "if it wants to take a more unilateral position and impose a legislative regime on reluctant or recalcitrant provinces."101 Jason MacLean, Meinhard Doelle, and Chris Tollefson similarly argue that "[t]he federal government's jurisdiction to make decisions based on the integration of social, economic,

Chalifour, "Climate Federalism," supra note 93 at 3. See e.g. Jason MacLean, Meinhard Doelle \& Chris Tollfeson, "Polyjural and Polycentric Sustainability Assessment: A Once-In-A-Generation Law Reform Opportunity" (2016) 30:1 J Envtl L \& Prac 35 [MacLean, Doelle \& Tollefson, "Polyjural and Polycentric Sustainability Assessment"]; Alastair R Lucas \& Jenette Yearsley, "The Constitutionality of Federal Climate Change Legislation" (2011) 4:15 University of Calgary SPP Research Papers 1; Hsu \& Elliot, supra note 94; Peter W Hogg, "Constitutional Authority Over Greenhouse Gas Emissions" (2009) 46:2 Alta L Rev 507; Nathalie J Chalifour, "Making Federalism Work for Climate Change: Canada's Division of Powers over Carbon Taxes" (2008) 22:2 NJCL 119; Nathalie J Chalifour, "The Constitutional Authority to Levy Carbon Taxes" in Thomas J Courchene \& John R Allan, eds, Canada: The State of the Federation 2009: Carbon Pricing and Environmental Federalism (Kingston: The Institute of Intergovernmental Relations, 2010) 177; Peter W Hogg, "A Question of Parliamentary Power: Criminal Law and the Control of Greenhouse Gas Emissions" (2008) CD Howe Institute Backgrounder No 114, online: < https://www.cdhowe.org/question-parliamentary-power-criminal-lawand-control-greenhouse-gas-emissions>; Stewart Elgie, "Kyoto, the Constitution, and Carbon Trading: Waking a Sleeping BNA Bear (or Two)" (2007) 13:1 Rev Const Stud 67; Kai D Sheffield, "The Constitutionality of a Federal Emissions Trading Regime" (2014) 4:1 Western J Leg Studies 1; Nigel D Bankes \& Alastair R Lucas, "Kyoto, Constitutional Law and Alberta's Proposals" (2004) 42:2 Alta L Rev 355; Elisabeth DeMarco, Robert Routliffe \& Heather Landymore, "Canadian Challenges in Implementing the Kyoto Protocol: A Cause for Harmonization" (2004) 42:1 Alta L Rev 209; Philip Barton, "Economic Instruments and the Kyoto Protocol: Can Parliament Implement Emissions Trading Without Provincial Co-Operation?" (2002) 40:2 Alta L Rev 417; Kathryn Harrison, "Challenges and Opportunities in Canadian Climate Policy" in Steven Bernstein et al, eds, A Globally Integrated Climate Policy for Canada (Toronto: University of Toronto Press, 2008) 336 [Harrison, "Challenges and Opportunities"]; Chris Rolfe, Turning Down the Heat: Emissions Trading and Canadian Implementation of the Kyoto Protocol (Vancouver: West Coast Environmental Law Research Foundation, 1998); Joseph F Castrilli, "Legal Authority for Emissions Trading in Canada" in Elizabeth Atkinson, ed, The Legislative Authority to Implement a Domestic Emissions Trading System (Ottawa: National Round Table on the Environment and the Economy, 1999) 7; Steven A Kennett, "Federal Environmental Jurisdiction After Oldman" (1993) 38:1 McGill LJ 180 at 187. Hsu \& Elliot, supra note 94 at 463.

Ibid; Canadian Environmental Assessment Act, SCC 1992, c 37.

100 Chalifour, "Climate Federalism," supra note 93 at 3. Notably, the Manitoba provincial government recently - if reluctantly - reached the same conclusion after seeking a legal opinion on the constitutional validity of the federal government's proposed pan-Canadian carbon price. See Government of Manitoba, News Release, "Province Releases Expert Legal Opinion on Carbon Pricing" (11 October 2017), online: Manitoba <news.gov.mb.ca/news/index.html?item=42320>. Hutchinson, "Climate Change," supra note 91. 
and environmental considerations is far broader than commonly understood." 102 Stepan Wood, Georgia Tanner, and Benjamin Richardson observe that in Canada "the primary obstacle to national leadership on the environment is a lack of political will on the part of successive federal governments rather than constitutionally imposed jurisdictional constraints." ${ }^{" 103}$ And as Kathryn Harrison pointedly concludes her comprehensive analysis of what I call environmental federalism 1.0, the federal government has historically been largely "ill-inclined to exercise its jurisdiction and [has taken] advantage of jurisdictional uncertainty by 'passing the buck' to jurisdictionally defensive provinces." 104

\section{B. Federalism 2.0: COOPERATION AND HARMONIZATION, or Still Passing the Buck?}

The legal clarity of the federal government's jurisdiction to legislate in respect of climate change does not, however, dispose of climate change's undeniable policy complexity. Nor does it exhaust the constitutional issues surrounding the creation of a national climate change policy. Given Canada's regionally distinct economies, federalism has thus far proven to be an obdurate political obstacle to adopting an integrated and effective climate change policy. ${ }^{105}$ Historically, Alberta has protected its oil and gas industry, Ontario has safeguarded its automotive industry, and Quebec has sought to uphold what it views as its exclusive political jurisdiction. ${ }^{106}$ Presently, Saskatchewan has begun to more aggressively assert the rights of its energy industry and its related natural resource extraction initiatives. ${ }^{107}$ Meanwhile, even the election of the New Democratic Party in British Columbia, made possible only by the support of the province's Green Party, has not appreciably enhanced the

MacLean, Doelle \& Tollefson, "Polyjural and Polycentric Sustainability Assessment," supra note 97 at 39 .

103 Stepan Wood, Georgia Tanner \& Benjamin J Richardson, "What Ever Happened to Canadian Environmental Law?" (2010) 37:4 Ecology LQ 981 at 1017, citing David R Boyd, Unnatural Law: Rethinking Canadian Environmental Law and Policy (Vancouver: UBC Press, 2003) at 92-93. See also Meinhard Doelle, The Federal Environmental Assessment Process: A Guide and Critique (Markham, Ont: LexisNexis, 2008) at 81:

The Supreme Court's approach to jurisdictional issues in the environmental field has been driven more by its recognition of the environment as an issue that requires the active engagement of all levels of government than a strict application of constitutional law principles.... The overall message to governments in Canada is that the SCC is not interested in being made the scapegoat for government inaction.

Kathryn Harrison, Passing the Buck: Federalism and Canadian Environmental Policy (Vancouver: UBC Press, 1996) at 162 [Harrison, Passing the Buck].

Kathryn Harrison, "The Road Not Taken: Climate Change Policy in Canada and the United States" (2007) 7:4 Global Environmental Politics 92.

Quebec's insistence on ensuring that the terminated interprovincial oil pipeline Energy East project also comply with the province's own environmental assessment regime is a case in point. Before the project was terminated, the pipeline proponent, TransCanada Corp, acceded to the province's demand that the project be reviewed by its Bureau d'audiences publiques sur l'environnement (BAPE). See Sidhartha Banerjee, "TransCanada to Produce Energy East Environmental Impact Study: Quebec," The Globe and Mail (22 April 2016), online: <https://www.theglobeandmail.com/news/national/transcanada-to-produce -energy-east-environmental-impact-study-quebec-says/article29728353/>. Another recent example is the province's reaction to the federal ministry of the Environment and Climate Change's issuance of an "emergency order" under the Species at Risk Act, SC 2002, c 29 that effectively blocked part of a residential development project south of Montreal in order to protect the habitat of the western chorus frog. Quebec's Environment Minister David Heurtel stated in response that the federal government's decision "raises serious questions about a potential intrusion in Quebec's jurisdiction": Daniel Leblanc, "Quebec Hopping Mad Over Federal Intervention to Protect Frog Habitat," The Globe and Mail (22 June 2016), online: <https://www.theglobeandmail.com/news/politics/quebec-slams-ottawa-for-unilateralaction-to-protect-frog-habitat/article30565269/>.

107 See e.g. Jason Markusoff, "Saskatchewan is Launching a Court Reference That Just Might Kill the Carbon Tax," Maclean's (25 April 2018), online: <https://www.macleans.ca/politics/saskatchewan-islaunching-a-court-reference-that-just-might-kill-the-carbon-tax/>. 
province's approach to environmental protection, climate change mitigation, or its relationship with Indigenous peoples. ${ }^{108}$ The environment and climate change policy landscape in Canada has long been, and remains, very much a fragmented and ultimately ineffective patchwork. ${ }^{109}$

Notably, while the Constitution itself is not an obstacle to effective pan-Canadian environmental legislation, it is often perceived as such. ${ }^{110}$ More importantly, it is often framed as being just such an obstacle. ${ }^{111}$ As a result, the pattern of federal-provincial dealings regarding the environment has taken the shape of disingenuous federal deference that calls for cooperation and harmonization. ${ }^{12}$ Prominent examples include the 1998 Canada-Wide Accord on Environmental Harmonization, ${ }^{113}$ which was concluded on the basis of "widespread yet dubious complaints of unnecessary duplication of federal and provincial legislation." 114 This accord "put the provinces firmly in the driver's seat and barred the federal government from acting whenever a province is designated the "lead' authority." 115 The Canadian Environmental Protection Act, $1999^{116}$ and the former Canadian Environmental Assessment $A c t^{117}$ similarly established a leading role for the provinces if they have equivalent regulatory standards. ${ }^{118}$ These federal enactments gave provincial governments the final word on just how stringently (or not) to assess the environmental impacts of proposed economic activities. ${ }^{119}$ Once again, under the dubious banners of

The governing NDP Party in British Columbia approved, in very short order, the continuation of the construction of the Site C hydroelectric dam megaproject over the concerns of environmentalists and Indigenous groups while also refusing to oppose its predecessor's approval of the Trans Mountain oil pipeline expansion, again over the concerns of environmentalists and Indigenous peoples. Most recently, the British Columbia government has publicly signaled its intention to subsidize and otherwise support the liquefied natural gas industry in the province. Thus, notwithstanding its laudable efforts to enhance the preparedness, response, and recovery relating to spills of diluted bitumen associated with the Trans Mountain pipeline, there is no discernible difference in environmental policy between the NDP government and the former Liberal government in British Columbia. See Jason MacLean, "The Trans Mountain Saga as a Public Policy Failure," Policy Options (13 April 2018), online: < policyoptions.irpp. $\mathrm{org} /$ magazines/april-2018/trans-mountain-saga-public-policy-failure/>.

Commissioner of the Environment and Sustainable Development, Report of the Commissioner of the Environment and Sustainable Development: The Commissioner's Perspective (Ottawa: Office of the Auditor General, 2014), online: <www.oag-bvg.gc.ca/internet/English/parl_cesd_201410_e_39845. html $>$ [Fall 2014 Report]. See also Josh Wingrove, "Scathing Report Details Canada's Environmental Shortfalls," The Globe and Mail (7 October 2014), online: < https://www.theglobeandmail.com/news/ politics/canada-lagging-on-emissions-goals-environment-watchdog-warns/article20959840/> [Wingrove, "Scathing Report]. MacLean, Doelle \& Tollefson, "Polyjural and Polycentric Sustainability Assessment," supra note 97 at $2-3$.

111 Harrison, Passing the Buck, supra note 104. For contemporary examples of this approach, see the Prime Minister's mandate letter to Minister of Natural Resources Jim Carr explaining to Minister Carr that "[w]e made a commitment to Canadians to pursue our goals with a renewed sense of collaboration. Improved partnerships with provincial, territorial, and municipal governments are essential to deliver the real, positive change that we promised Canadians" (Office of the Prime Minister, "Minister of Natural Resources Mandate Letter" (12 November 2015), online: $<$ https://pm.gc.ca/eng/minister-naturalresources-mandate-letter>). Identical language is included in the Prime Minister's mandate letter to the Minister of Environment and Climate Change: Prime Minister's Office, "Minister of Environment and Climate Change Mandate Letter" (12 November 2015), online: <https://pm.gc.ca/eng/ministerenvironment-and-climate-change-mandate-letter>. Wood, Tanner \& Richardson, supra note 103 at 1019 Canadian Council of Ministers of the Environment, A Canada-Wide Accord on Environmental Harmonization (Ottawa, 1998), online: <www.ccme.ca/en/resources/harmonization/index.html . Wood, Tanner \& Richardson, supra note 103 at 1019.

Ibid.

SC 1999, c 33, s 10(3).

Supra note 99, s 54(1).

Wood, Tanner \& Richardson, supra note 103 at 1019.

Melody Hessing, Michael Howlett \& Tracy Summerville, Canadian Natural Resource and Environmental Policy: Political Economy and Public Policy, 2nd ed (Vancouver: UBC Press, 2005) at 205, cited in Wood, Tanner \& Richardson, ibid. 
cooperation and harmonization, the federal government effectively "passed the buck" by delegating its environmental responsibilities to the provinces. ${ }^{120}$

The Canadian Environmental Assessment Act, $2012^{121}$ significantly extended this practice. When the previous version of the Act came up for review, British Columbia argued forcefully that economic activity in the province was being hampered by the overlapping jurisdiction of the federal and provincial environmental assessment regimes; as of 2011, approximately 60 percent (42 of 71) of provincial projects were subject to both regimes. ${ }^{122}$ British Columbia argued that instead of "harmonization," the federal government should exempt most projects based in the province from the federal environmental assessment regime if the project was subject to an assessment led by British Columbia. Under this proposed approach, project proponents would only be required to undergo "a single (provincial) assessment." 123 The province maintained that the British Columbia environmental assessment process "meets or exceeds the [rigour] of the federal environmental assessment process." ${ }^{24}$ The following year, when the Harper government unveiled CEAA, 2012, British Columbia's proposed amendments were embodied largely intact in the new law.

Patricia Fitzpatrick and A. John Sinclair describe CEAA, 2012 as federal environmental assessment "retrenchment." ${ }^{125}$ Retrenchment, they argue, is a deliberate strategy of "limiting the application of federal EA." 126 In the context of multijurisdictional environmental assessments, CEAA, 2012 establishes three new mechanisms through which the federal government may "pass the buck" in respect of its environmental assessment obligation: (1) delegation; ${ }^{127}$ (2) substitution; ${ }^{128}$ and (3) exemption. ${ }^{129}$

Under both the delegation and substitution mechanisms, the federal government arrogated to itself the power to pass off its environmental assessment obligations to a province or territory in respect of projects that would otherwise require a federal assessment; the federal government retains the right — but not the obligation — to make the ultimate project decision on the basis of the delegated or substituted assessment. The exemption mechanism goes even further. Where this power is exercised, the federal government forfeits its right to make the final decision regarding the assessed project. ${ }^{130}$

Wood, Tanner \& Richardson, ibid. See also Patricia Fitzpatrick \& A John Sinclair, "Multi-Jurisdictional Environmental Assessment in Canada" in Kevin S Hanna, ed, Environmental Impact Assessment: Practice and Participation, 3rd ed (Don Mills, Ont: Oxford University Press, 2016) 182 at 184 (arguing that actual progress toward harmonizing the legal architecture and requirements of Canadian environmental assessment regimes has been modest at best).

121 SC 2012, c 19, s 52 [CEAA, 2012].

122 MacLean, Doelle \& Tollefson, "Polyjural and Polycentric Sustainability Assessment," supra note 97 at 49 .

Ibid at 50 .

Ibid.

Fitzpatrick \& Sinclair, supra note 120 at 189. See also Robert B Gibson, "In Full Retreat: The Canadian Government's New Environmental Assessment Law Undoes Decades of Progress" (2012) 30:3 Impact Assessment \& Project Appraisal 179.

Fitzpatrick \& Sinclair, ibid.

CEAA, 2012, supra note 121, s 26.

Ibid, $\mathrm{s} 32$.

Ibid, s 37.

See MacLean, Doelle \& Tollefson, "Polyjural and Polycentric Sustainability Assessment," supra note 97. 
According to the British Columbia Environmental Assessment Office, the province has persuaded the federal government to exercise its new substitution powers early and often, totaling as of this writing fourteen assessments, primarily in respect of mining and liquefied natural gas $(\mathrm{LNG})$ projects. ${ }^{131}$

Just as Wood, Tanner, and Richardson concluded that collaborative federalism and harmonization largely failed to improve environmental governance generally, ${ }^{132}$ retrenchment has thus far proved equally disappointing. ${ }^{133}$ Following the enactment of CEAA, 2012, the federal government has failed to establish clear guidelines regarding which economic activities and project proposals require an environmental assessment. As the Commissioner of the Environment and Sustainable Development concluded in her 2014 audit, the consequence of this failure is that "some significant projects will not be adequately assessed." 134

Most recently, in her Fall 2017 Report, the Commissioner noted that the federal government has yet to transition "from a seemingly endless planning mode into an action mode", and concluded that "in two important areas-reducing greenhouse gases and adapting to the impacts of climate change - the federal government has yet to do much of the hard work that is required to bring about this fundamental shift."135

Meanwhile, at the provincial level, some provinces "have taken advantage of Ottawa's timidity to keep their own laws weak." ${ }^{136}$ British Columbia's proposed new climate change policy ${ }^{137}$ (under its former Liberal government), for example, resulted in renewed calls for a stronger federal role in environmental governance, particularly in respect of climate change. ${ }^{138}$ Andrew Gage of the West Coast Environmental Law Clinic expressed the issue this way: "the important thing is that each province has a plan that credibly and transparently shows how it will achieve its [GHG reduction] targets and/or its fair share of Canada's

For additional and up-to-date details, see the website of the British Columbia Environmental Assessment Office, online: <www.eao.gov.bc.ca>.

Wood, Tanner \& Richardson, supra note 103 at 1020.

MacLean, Doelle \& Tollefson, "Polyjural and Polycentric Sustainability Assessment," supra note 97. Fall 2014 Report, supra note 109 at 3.

Commissioner of the Environment and Sustainable Development, Reports of the Commissioner of the Environment and Sustainable Development to the Parliament of Canada: The Commissioner's Perspective (Ottawa: Office of the Auditor General, 2017) at 1,3, online: <www.oag-bvg.gc.ca/internet/ English/parl_cesd_2017 10_00_e_42488.html> Fall 2017 Report].

136 Wood, Tanner \& Richardson, supra note 103 at 1020. See also Jason MacLean, "Ontario's Cap-andTrade Regime Off to a Shaky Start," Toronto Star (3 March 2016), online: <https://www.thestar.com/ opinion/commentary/2016/03/03/ontarios-cap-and-trade-regime-off-to-a-shaky-start.html> (arguing that Ontario's new cap-and-trade regime is unlikely to assist the province in meeting its or Canada's GHG reduction target because of the regime's initial and indefinite exemption of approximately 14 percent of Ontario's large GHG emitters and its insufficiently stringent carbon price).

137 Government of British Columbia, Climate Leadership Plan (Victoria: Government of British Columbia, 2016), online: <https://climate.gov.bc.ca/app/uploads/sites/13/2016/10/4030 CLP Booklet web.pdf>. But see Mark Jaccard, "B.C.'s Climate Plan Reaches Olympian Heights of Political Cynicism," The Globe and Mail (21 August 2016), online: <https://www.theglobeandmail.com/opinion/bcs-climateplan-reaches-olympian-heights-of-political-cynicism/article31464244/>.

138 See e.g. Ian Bailey, "B.C. Environmental Law Group Criticizes Federal Approach to Climate Change," The Globe and Mail (31 August 2016), online: <https://www.theglobeandmail.com/news/britishcolumbia/bc-environmental-law-group-criticizes-federal-approach-to-climate-change/article31656437/>. 
national target. Accountability must be an integral part of the national framework that you are in the process of developing, from both a fairness and an efficacy perspective."139

The absence of federal leadership has also hampered Canada's efforts to promote and institutionalize sustainability. ${ }^{140} \mathrm{~A}$ case in point is the unfulfilled promise of the Federal Sustainable Development Act, ${ }^{141}$ which is explored briefly below.

\section{WHATEVER HAPPENED TO THE FEDERAL SUSTAINABLE DEVELOPMENT ACT?}

In 2008 the minority federal government supported a Liberal private member's bill to create a Federal Sustainable Development Act. Two aspects of the Act are notable. The first is the federal government's acceptance of "the basic principle that sustainable development is based on an ecologically efficient use of natural, social and economic resources"142 and the government's accompanying acknowledgment of "the need to integrate environmental, economic and social factors in the making of all decisions by government." 143 The second is the Act's core purpose of providing "the legal framework for developing and implementing a Federal Sustainable Development Strategy that will make environmental decision-making more transparent and accountable to Parliament." 144 This Strategy, which was to be initially developed by 2010 and then renewed within every three-year period hence, is also to be "based on the precautionary principle." 145 The Federal Sustainable Development Act is thus a remarkably ambitious legislative instrument (at least on its face).

It is also a curious one, given that the initial Federal Sustainable Development Strategy period (2010-2013) $)^{146}$ coincided with the federal government's retrenchment from environmental assessment and environmental governance more generally. ${ }^{147}$ Glen Toner, James Meadowcroft, and David Cherniak argue that this ostensible contradiction is due to the previous federal government's cunning cooptation of the discourse of sustainability as a form of "empty rhetoric" deployed to promote the federal government's altogether unsustainable "Responsible Resource Development" agenda. ${ }^{148}$ Their argument is supported

Andrew Gage, "BC's Climate Plan Shows Why Real Leadership Requires Accountability," West Coast Environmental Law Clinic (30 August 2016), online: $<$ https://www.wcel.org/resources/environmentallaw-alert/bc-climate-plan-shows-why-real-leadership-requires-accountabilit>.

140 See e.g. Glen Toner, James Meadowcroft \& David Cherniak, "The Struggle of the Canadian Federal Government to Institutionalize Sustainable Development," in Debora L VanNijnatten, ed, Canadian Environmental Policy and Politics: The Challenges of Austerity and Ambivalence, 4th ed (Don Mills, Ont: Oxford University Press, 2016) 116 at 116-29. See also Mark Winfield, "Decision-Making, Governance and Sustainability: Beyond the Age of 'Responsible Resource Development"' (2016) 29 J Envtl L \& Prac 129; Rod Northey, "Fading Role of Alternatives in Federal Environmental Assessment" (2016) 29 J Envtl L \& Prac 41. SC 2008 , c 33 .

Ibid, s 5 .

Ibid [emphasis added].

Ibid, $\mathrm{s} 3$.

Ibid, s 9(1).

Environment Canada, Planning for a Sustainable Future: A Federal Sustainable Development Strategy for Canada (Ottawa: Sustainable Development Office, 2010).

${ }_{147}$ The federal government's overall retrenchment, including but extending beyond its environmental assessment regime, was accomplished through its "Responsible Resource Development" initiative, which was ushered in by the controversial omnibus Bill C-38, or the Jobs, Growth and Long-term Prosperity Act, SC 2012, c 19. The term "streamlining" is also used to characterize this move. See Alan Bond et al, "Impact Assessment: Eroding Benefits Through Streamlining?" (2014) 45 Environmental Impact Assessment Rev 46. 
by the audits of the Federal Sustainable Development Strategy conducted by the Commissioner of the Environment and Sustainable Development. The Commissioner's audit of the federal government's 2012 "Progress Report," for example, criticized the government for misleading Canadians by failing to present "a representative, clear and complete picture," explaining that "balanced reporting [is necessary to ensure] there are no distortions of information through presentation or tone, or through the omission of information and context." 149 The Commissioner's critique referred to the government's portrayal of Canada as being well on its way to meeting the GHG emissions reduction target that it pledged in Copenhagen in $2009^{150}$ when, at the same time, Environment Canada's own data unequivocally indicated that due to rapidly increasing GHG emissions from Alberta's oil sands, Canada was on course to exceed its Copenhagen target by 20 percent. ${ }^{151}$ The Commissioner concluded her initial audit by noting that the federal government had failed to provide Canadians with a fair and balanced account of its progress towards acheiving its stated climate change mitigation and sustainability aspirations. ${ }^{152}$

Similarly, the potential of the renewed 2013-2016 Federal Sustainable Development Strategy has not been realized. In her 2014 report, the Commissioner of the Environment and Sustainable Development observed that "Environment Canada is not coordinating with the provinces and territories to achieve the national [GHG emissions reduction] target."153 Regarding the related and crucially important issue of a regulatory framework for the oil and gas sector, where GHG emissions continue to increase more rapidly than in any other sector of the economy, the Commissioner noted that while "detailed regulatory proposals have been available internally for over a year," the government had only consulted privately, largely through a "small working group of one province and selected industry representatives." 154 The Commissioner concluded her 2014 report thus: in "many key areas that we looked at, it is not clear how the government intends to address the significant environmental challenges that future growth and development will likely bring about." 155

Commissioner of the Environment and Sustainable Development, Report of the Commissioner of the Environment and Sustainable Development (Ottawa: Office of the Auditor General, 2013), ch 8, ss 8.45, 8.70 [Commissioner of the Environment and Sustainable Development, "Review of 2012 Progress Report"].

150 As part of the Copenhagen Accord concluded in 2009, Canada committed to reduce its GHG emissions by 17 percent of 2005 levels by the year 2020. See Kathleen Harris, "Canada Failing to Meet 2020 Emissions Targets," CBC News (24 October 2013), online: <www.cbc.ca/news/politics/canada-failingto-meet-2020-emissions-targets-1.2223930>.

151 Environment Canada, Canada's Emissions Trends (Ottawa: Environment Canada, 2013), online: <https://www.ec.gc.ca/ges-ghg/985F05FB-4744-4269-8C1A-D443F8A86814/1001-Canada\% $27 \mathrm{~s} \% 20$ Emissions $\% 20$ Trends $\% 202013$ e.pdf $>$.

152 Commissioner of the Environment and Sustainable Development, "Review of 2012 Progress Report," supra note 149 , ch 8 , ss $8.70-8.73$.

153 Fall 2014 Report, supra note 109, s 1.30. See also Commissioner of the Environment and Sustainable Development, Report of the Commissioner of the Environment and Sustainable Development (Ottawa, OAG, 2015), online: <www.oag-bvg.gc.ca/internet/English/parl_cesd_201512_e_41007. html > [Fall 2015 Report].

154 Fall 2014 Report, ibid, s 1.19. See also Mark S Winfield, Clare Demerse \& Johanne Whitmore, "Climate Change and Canadian Energy Policy" in Steven Bernstein et al, eds, A Globally Integrated Climate Policy for Canada, (Toronto: University of Toronto Press, 2008) 261 (arguing that the federal government has failed "to develop an overall strategy to re-orient Canada's energy path away from conventional non-renewable energy development and export and towards greater energy efficiency and reliance on low-impact renewable energy sources" at 266).

155 Office of the Auditor General of Canada, "Commissioner of the Environment and Sustainable Development Releases Fall 2014 Report” (7 October 2014), online: <www.oag-bvg.gc.ca/internet/ English/osh_20141008_e_39915.html >. See also Wingrove, "Scathing Report," supra note 109. The Commissioner reaches substantially the same conclusion in her 2015 report but frames it in comparatively more optimistic language, presumably in light of the intervening change in government 
The successive failures of the Federal Sustainable Development Strategy neatly illustrate that, when it comes to federalism and environmental protection, the most pressing constitutional issue is hardly one of federal versus provincial jurisdiction. ${ }^{156}$ Nor is it one of intergovernmental accountability. Neither the federal nor the provincial governments of Canada can claim superiority — much less success - in promoting environmental protection and sustainability. ${ }^{157}$ Harrison concludes her landmark study of federalism and Canadian environmental policy by observing that "governments generally will be unwilling to pursue policies to protect the environment, although their reluctance may be briefly overcome during periods of exceptional public attentiveness to environmental issues. ${ }^{\prime 158}$ Harrison's conclusion gestures toward an altogether different federalism issue in respect of the public's interest in effective climate change mitigation and a fair and efficient transition to sustainability. The most pressing federalism issue in respect of Canadian environmental law and policy is the federal government's direct accountability to Canadians, whose trust the current government has repeatedly vowed to restore. This altogether different issue calls for an altogether different approach to federalism and national policymaking more generally — call it federalism 3.0. ${ }^{159}$ The next part of this article unpacks and critically examines the constitutive elements of this new approach and discusses its implications for Canada's initial climate change and sustainability policies and decisions.

\section{Canadian Climate Change Policy and Federalism 3.0 - From Retrenchment to Restoring CanAdians' Trust}

"Canada is back." Or so declared Prime Minister Justin Trudeau at the outset of the final Paris climate change negotiations in November 2015, telling the conference delegates that Canada was ready to assume a new climate leadership role on the international stage. ${ }^{160}$ Back at home, the first visible manifestation of this new commitment arose out of the First

at the federal level: "Canada has embraced the two sides of the coin: combatting climate change and its impacts, and working to achieve sustainable development. Concrete actions on these commitments will put Canada on the road to meeting the needs of present and future generations. I look forward to reporting to Parliament on the government's progress in achieving these all-important goals" (Fall 2015 Report, supra note 153).

156 But see Andrew J Green, "Bringing Institutions and Individuals into a Climate Policy for Canada" in Bernstein et al, supra note 153, 247 (arguing that "it is not at all clear that the federal government has the constitutional jurisdiction to put in place a national system" at 249).

157 As of this writing, for example, the present federal government, after being an outspoken member of the "High Ambition Coalition" during the Paris climate change agreement negotiations, refused to update the former Conservative federal government's GHG emissions reduction target of 30 percent below the 2005 level by 2030, despite having previously characterized the Conservative's target as "unambitious" and, even more pointedly, as "fake" (Payton, supra note 42).

158 Harrison, Passing the Buck, supra note 104 at 162 [emphasis added]. Douglas Macdonald reaches a similar conclusion with respect to the ability of industry to avoid stringent environmental regulations, observing that Canadian business "is less powerful when fighting high-profile issues that have mobilized counter-vailing forces" (Douglas Macdonald, Business and Environmental Politics in Canada (Peterborough, Ont: Broadview Press, 2007) at 191).

159 The concept of federalism 3.0, coined for the sake of analytical convenience, is inspired by Roderick Macdonald \& Robert Wolfe's conception of Canada's third national policy, or NP3, and seeks to test the normative predictions made by Macdonald \& Wolfe in respect of the evolution of NP3 in the context of Canada's emerging climate governance: Roderick A Macdonald \& Robert Wolfe, "Canada's Third National Policy: The Epiphenomenal or the Real Constitution?" (2009) 59:4 UTLJ 469 at 522. See also Roderick A Macdonald, "Kaleidoscopic Federalism" in Jean-François Gaudreault-DesBiens \& Fabien Gélinas, eds, The States and Moods of Federalism: Governance, Identity and Methodology (Cowansville, Que: Éditions Yvon Blais, 2005) 261 at 261. In the specific context of climate change, see MacLean, “Autonomy in the Anthropocene?," supra note 7.

160 James Fitz-Morris, "Justin Trudeau Tells Paris Climate Summit Canada Ready to Do More," CBC News (30 November 2015), online: <www.cbc.ca/news/politics/trudeau-address-climate-change-paris$1.3343394>$. 
Ministers' Meeting on climate change and the release of the "Vancouver Declaration on Clean Growth and Climate Change." "I61 In the "Vancouver Declaration," the federal, provincial, and territorial governments agreed to "build on the momentum of the Paris Agreement by developing a concrete plan to achieve Canada's international commitments through a pan-Canadian framework for clean growth and climate change."162 To that end, the First Ministers recognized "that the level of ambition set by the Paris Agreement will require global emissions to approach zero by the second half of the century and that all governments, Indigenous peoples, as well as civil society, business and individual Canadians, should be mobilized in order to face this challenge." 163 Instigated by the federal government, the discourse of the "Vancouver Declaration" is an example of what Macdonald and Wolfe characterize as "the constitutional (constitutive) conversation of the future [which] will be couched in the rhetoric of policy, purposes, and human agency, not that of jurisdiction, power, and imposed authority." 164 What does this new and aspirational constitutional (constitutive) conversation - what Macdonald and Wolfe call Canada's "Third National Policy," or "NP3" — involve, and what are its implications for Canada's evolving climate change policies? More pointedly, will Canada's emerging climate change policies vindicate its commitments under the Paris Agreement and fulfil its own promises of a democratically enhanced mode of environmental governance (federalism 3.0)?

\section{A. Canada's Third National Policy, OR LET'S TALK TV?}

Macdonald and Wolfe conceive of national policies as both collective, normative endeavours originating in the actions and demands of citizens, and also as analytic frameworks. Moreover, they argue that national policies are more constitutive of the Canadian state and its governing instruments than any of its renamed Constitution Acts, which they view as epiphenomenal. ${ }^{166}$

Canada's national policy, they argue, has evolved from the creation of a resource-wealthy transcontinental country (NP1), to the establishment of an administrative state tasked with widely redistributing the fruits of the country's transcontinental wealth (NP2), to enhancing citizens' agency (NP3). ${ }^{167}$ The primary and ongoing ambition of NP3 is to "unbundle programs and reaggregate policy goals now largely managed by centralized bureaucracies (both public and private) ... in ways that enhance the ability of citizens to lead self-directed

Canadian Intergovernmental Conference Secretariat, "Vancouver Declaration on Clean Growth and Climate Change" (3 March 2016), online: <https://itk.ca/wp-content/uploads/2016/04/Vancouver Declaration_clean_Growth_Climate_Change.pdf $>$ [Canadian Intergovernmental Conference Secretariat, "Vancouver Decläration"].

Ibid at 1.

163 Ibid. The "Vancouver Declaration" relatedly recognizes "the importance of public education, participation and access to information to increase climate change awareness and literacy" (ibid at 5). However, and perhaps tellingly, the "Vancouver Declaration" emphasizes "the diversity of provincial and territorial economies" and, in particular, "the economic importance of Canada's energy and resource sectors, and their sustainable development as Canada transitions to a low carbon economy" (ibid at 2 [emphasis added]).

Ibid.

Ibid at 494. 
lives in concert with others, surely the litmus test for a liberal democracy." ${ }^{168}$ In order to give full effect to this emergent third national policy, Macdonald and Wolfe argue:

[G]overnments at all levels are experimenting with new policy instruments, new forms of civic engagement, and new processes and channels through which bi-directional communication and understanding may be negotiated and refashioned. The political challenge of NP3, then, lies in finding models of participation and accountability that ensure a continuation of the democratic ideal of citizen equality in an unstable, plural, relatively boundary-less universe of policy implementation. ${ }^{169}$

Macdonald and Wolfe argue that government instruments such as the Constitution Act, 1982, ${ }^{170}$ the Macdonald Royal Commission, ${ }^{171}$ the Free Trade Agreement, ${ }^{172}$ NAFTA, ${ }^{173}$ the Goods and Services Tax, ${ }^{174}$ the Royal Commission on Aboriginal Peoples, ${ }^{175}$ and the Nisga'a Final Agreement ${ }^{176}$ "can be seen as competing diagnoses of and competing legal responses to a perceived need to articulate a third National Policy." 177

To this list one could add still more explicit examples, including: (1) Canada's Action Plan on Open Government, which "seeks to engage citizens in public dialogue that will inform the policy creation process and contribute directly to more responsive, innovative and effective governance"; ${ }^{178}$ (2) the federal government's commitment to a "true partnership" — cooperation and collaboration — with the provinces and territories; ${ }^{179}$ and (3) the federal

\section{Ibid.}

Ibid at 505 [footnote omitted] [emphasis added]. In the US constitutional context a similar argument is advanced in Michael C Dorf \& Charles F Sabel, "A Constitution of Democratic Experimentalism" (1998) 98:2 Colum L Rev 267.

Being Schedule B to the Canada Act 1982 (UK), 1982, c 11

Donald S Macdonald et al, Report of the Royal Commission on the Economic Union and Development Prospects for Canada, (Ottawa: Privy Council Office, 1985), online: <publications.gc.ca/site/eng/ 472251/publication.html>.

Government of Canada, The Canada-US Free Trade Agreement, online: <www.international.gc.ca/ trade-agreements-accords-commerciaux/assets/pdfs/cusfta-e.pdf $>$.

North American Free Trade Agreement Between the Government of Canada, the Government of Mexico and the Government of the United States, 17 December 1992, Can TS 1994 No 2 (entered into force 1 January 1994), online: <https://www.italaw.com/sites/default/files/laws/italaw6187\%286\%29.pdf>. See Richard Domingue \& Jean Soucy, "The Goods and Services Tax: 10 Years Later," Government of Canada Publication PRB 00-03E (15 June 2000), online: <publications.gc.ca/Collection-R/LoPBdP/ $\mathrm{BP} / \mathrm{prb0003}$-e.htm>.

Mary C Hurley \& Jill Wherrett, "The Report of the Royal Commission on Aboriginal Peoples" Parliamentary Research Branch Brief 99-24E (Ottawa: Library of Parliament, 1999), online: <https:// www.lop.parl.gc.ca/content/lop/researchpublications/prb9924-e.htm>.

Nisga'a Final Agreement Act, SC 2000, c7.

Macdonald \& Wolfe, supra note 159 at 522.

Government of Canada, "Canada's Action Plan on Open Government 2012-2014," online: $<$ data.gc.ca/eng/canadas-action-plan-open-government $>$ [emphasis added]. Canada is also part of the Open Government Partnership, an international platform for domestic reformers committed to making their governments more open to the public. According to the federal government: "[w]ithin Canada, the Open Government Partnership provides us with a real opportunity to accelerate the transformation of our public service and of our government through a fundamental openness to working with Canadians" (ibid [emphasis added]). See also Open Government Partnership, online: < https://www.opengov partnership.org $>$. Finally, soon after its election, the Trudeau federal government implemented an "Open and Accountable Government" policy, which provides, among other things, that "[ $\mathrm{t}]$ here should be no preferential access to government, or appearance of preferential access, accorded to individuals or organizations because they have made financial contributions to politicians and political parties" (Government of Canada, Open and Accountable Government (Ottawa: Privy Council Office, 2015) at 24, online: <https:/www.pm.gc.ca/eng/news/2015/11/27/open-and-accountable-government $>$ ). “Canada Election 2015: Trudeau Promises ‘True Partnership' With Provinces," CBC News (22 August 2015), online: $<$ www.cbc.ca/news/politics/canada-election-2015-learned-this-week-aug22-1.3200542>. 
government's commitment to reconciliation and a new, nation-to-nation relationship with Indigenous peoples. ${ }^{180}$

In order to unpack the elements of this new aspirational and responsive approach to federalism, consider the Canadian Radio-television and Telecommunications Commission's (CRTC) recent initiative "Let's Talk TV: A Conversation with Canadians" launched in 2013. ${ }^{181}$ The objective of the CRTC's "Let's Talk TV" was to explore options for the future of Canadians' television system and how it can adapt to changing technologies and viewing habits. ${ }^{182}$ The initiative's first phase featured an online solicitation of comments. In particular, the CRTC asked Canadians to share their open-ended views on television programming, and asked Canadians whether they have sufficient information to make choices and whether they knew where to turn if they are not satisfied. The comments received during phase one informed and helped shape phase two of the initiative, the "Let's Talk TV Choicebook," an interactive questionnaire designed to

provide an opportunity to consider some of the issues that have been raised, as well as the perspectives of other Canadians, and explore some of the trade-offs associated with certain options. Ultimately, this input will help shape a proposed framework that is flexible and responsive to a communication environment that is in constant flux. ${ }^{183}$

The Choicebook was followed by both a formal proceeding and a public hearing. ${ }^{184}$ The CRTC received over 13,000 comments from Canadians through the various phases of "Let's Talk TV." 185

Decisions taken pursuant to the "Let's Talk TV" initiative include the elimination of 30day cancellation policies; the promotion of Canadian-made content; the implementation of measures to improve access for Canadians with disabilities to content that meets their needs; a new Code of Conduct for broadcasters and TV service providers; enabling Canadians to watch live Super Bowl advertisements by the end of the 2016 season; and the introduction of a new, affordable entry-level service capped at $\$ 25$ per month, ${ }^{186}$ also known as the "skinny basic" TV package. ${ }^{187}$ Notably, after the initial "skinny packages" arrived, consumers complained that the TV providers added extra costs for hardware and designed the packages to be unappealing, prompting the CRTC's Chairman, Jean-Pierre Blais, to call the four-largest TV providers in Canada before a public hearing to answer for the consumer frustration. In response, Rogers promised to offer bundle discounts with its skinny package,

Liberal Party of Canada, "A New Nation-To-Nation Process," online: <https://www.liberal.ca/real change/a-new-nation-to-nation-process/>.

CRTC, "Let's Talk TV: A Conversation with Canadians," online: <https://www.crtc.gc.ca/eng/talktvparlonstele.htm> [CRTC, "Let's Talk TV"].

CRTC, News Release, "Let's Talk TV: CRTC Sets Out a Roadmap to Maximize Choice and Affordability for Canadian TV Viewers" (19 March 2015), online: <https://web.archive.org/web/2015 0513190111/http://news.gc.ca/web/article-en.do?nid=952659>.

CRTC, "Let's Talk TV: A Report on Comments Received During Phase I" (Ottawa: CRTC, 2014) at 2.

CRTC, "Let's Talk TV," supra note 181.

CRTC, "Navigating the Road Ahead: Making Informed Choices About Television Providers and Improving Accessibility to Television Programming" (Ottawa: CRTC, 2015).

CRTC, "Let's Talk TV," supra note 181.

James Bradshaw \& Christine Dobby, "How 'The Blais Show' Shook Up Canadian Telecom,” The Globe and Mail (9 September 2016), online: $<$ https://www.theglobeandmail.com/report-on-business/blais-crtcprofile/article31797971/>. 
and Bell promised it would stop requiring some customers to subscribe to its Internet service in order to get its skinny TV option. ${ }^{188}$

The broader regulatory context of the CRTC's "Let's Talk TV" initiative aligns closely with the core principles of NP3 and federalism 3.0. Under the leadership of the CRTC's Chair Jean-Pierre Blais, whose five-year term began in 2012, the CRTC endeavoured to transform itself by 2017 into an institution that is "trusted by Canadians" and no longer "in the pockets of the big companies" of the CDN\$63-billion industry that it regulates. ${ }^{189}$ In a remarkably - and refreshingly - candid response to industry complaints that the CRTC under Blais' leadership tended toward a more formal, public hearing-based approach to dialogue, Blais countered that what the industry players want is "that informal 'yeah yeah, nudge nudge, wink wink, your application will be approved'... 'If that's what they want, they're not going to get it from me and my commission." ${ }^{\prime 190}$ Asked if he thought Canadians will ever truly be convinced, Blais responded that " $[\mathrm{t}] \mathrm{ime}$ will tell whether it's irreversible, but I do think the institution is more focused on Canadians than ever before."191

At the same time, various federal governments' genuine commitment to aspirational federalism may be questioned. As part of the federal government's recent environmental policy "retrenchment" discussed above, for instance, the federal government severely restricted the ability of Canadians to participate in the public hearings conducted by the National Energy Board assessing major energy projects, including interprovincial oil pipeline proposals. In 2012, for instance, the federal government amended the National Energy Board $A c t^{192}$ by adding section 55.2, which allows the Board to grant public participation rights only to those Canadians who in the Board's sole discretion are "directly affected by the granting or refusing of the application." ${ }^{\prime 193}$ The National Energy Board has interpreted this standard narrowly, with full deference from the Federal Court of Appeal, ${ }^{194}$ notwithstanding that the Board describes its own mandate as regulating pipelines, energy development, and trade in "the Canadian public interest," which it defines as "inclusive of all Canadians and refers to a balance of economic, environmental and social considerations that changes as society's values and preferences evolve over time." 195

Tellingly, Macdonald and Wolfe's approach to examining the Canadian Constitution as an epiphenomenon of an underlying and evolving national policy is at once positive and normative; they favour aspirational federalism (or NP3) and point to a number of instruments indicative of its core commitments (chief among them, perhaps, being the Charter of Rights and Freedoms, which embodies a direct relationship between state and citizen); but they also

Ibid. See also Terry Pedwell, "Consumer Groups Urge CRTC to Ban Discriminatory TV Discount Plans," The Globe and Mail (8 September 2016), online: $<$ https://www.theglobeandmail.com/report-onbusiness/consumer-groups-want-crtc-to-ban-discriminatory-basic-tv-offerings/article31763165/>. Bradshaw \& Dobby, supra note 187.

Ibid.

Ibid.

RSC 1985, c N-7.

Ibid, s 55.2.

Forest Ethics Advocacy Association v National Energy Board, 2014 FCA 245, 465 NR 152.

National Energy Board, "Strategic Plan," online: $<$ https://web.archive.org/web/201706150543/ https:// www.neb-one.gc.ca/bts/whwr/gvrnnc/strtgcpln-eng.pdf> [emphasis added]. The current federal government has committed to reviewing and reforming the National Energy Board. See Government of Canada, "A New Canadian Energy Regulator" (8 February 2018), online: < https://www.canada.ca/en/ services/environment/conservation/assessments/environmental-reviews/national-energy-boardmodernization.html $>$. 
reflexively question whether Canada still has a national policy, given the broad and deep political apathy and cynicism of citizens in Canada. ${ }^{196}$ Put another way, they ask whether "Canadians have a shared, if unarticulated, sense of what they wish to do together that shapes their understanding of the goals and tools of governance?"197 This, in turn, raises the question of whether the current federal government is truly committed to adopting and delivering on policies that prioritize the preferences of Canadians, including Indigenous peoples and local communities on the front lines of natural resource development projects. The most revealing answers to these fateful questions may well be found in an examination of the current federal government's approach to public consultation in respect of its emerging climate change policies, as well as its initial policy planks and decisions on controversial natural resources projects.

\section{B. Let's Talk Climate Action, OR CHECK-THE-BOX CONSTITUTIONALISM?}

Notwithstanding the old chestnut that Canadians' concern for the environment is a mile wide and an inch deep, ${ }^{198}$ a quickly-growing body of recent evidence suggests that Canadians now support strong government action on climate change. Moreover, Canadians appear to want to have a say in how the government makes decisions on policies and projects having significant climate change implications.

\section{CANADIANS'SUPPORT FOR A New National Climate Policy}

In April 2015 a representative poll of 3,040 Canadians conducted by Oracle Research for the Climate Action Network Canada found that 61 percent of Canadians agreed or strongly agreed with the proposition that "[p]rotecting the climate is more important than building the Energy East pipeline and further developing the tar sands." ${ }^{.199}$ Over 80 percent of Canadians in the poll were familiar with the Energy East oil pipeline project, and by a three-to-one margin, respondents agreed or strongly agreed that "[b]uilding the Energy East pipeline to export tarsands oil is unethical because it is harmful to the environment." ${ }^{200}$ Notably, 78 percent of respondents signaled a desire "to have a say in decision-making about projects like the tarsands and Energy East." 201

In or around the same time, a national poll conducted by Angus Reid found that most Canadians supported carbon pricing in one form or another, and saw climate change as an electoral issue. ${ }^{202}$ Over half ( 56 percent) believed that the federal government was not doing

\footnotetext{
$196 \quad$ Macdonald \& Wolfe, supra note 159 at 472.

Ibid [emphasis in original].

Boyd, supra note 103 at 265.

Climate Action Network Canada, " $61 \%$ of Canadians Say Protecting the Climate More Important Than Pipelines and Tarsands" (8 April 2015), online: <https://climateactionnetwork.ca/2015/04/07/61-ofcanadians-say-protecting-the-climate-more-important-than-pipelines-and-tarsands/ $>$.

Ibid.

201 Ibid. Relatedly, 85 percent of respondents believed that the proponent of Energy East, TransCanada Corp., should be required to translate its project-related documents into French to allow Francophone Canadians to properly review the project.

202 Carol Linnitt, "Most Canadians Support Carbon Pricing, See Climate as Election Issue: New Poll," The Narwhal (22 April 2015), online: <https://thenarwhal.ca/most-canadians-support-carbon-pricing-seeclimate-election-issue-new-poll>.
} 
enough on climate change, and 75 percent and 56 percent of those polled supported a national cap-and-trade or carbon tax policy, respectively. ${ }^{203}$

Moreover, in a poll conducted just before Prime Minister Trudeau attended at the UN climate change negotiations in Paris late in 2015, the Nanos Research Group found that 73 percent of a representative sample of 1,000 Canadians agreed or somewhat agreed that "climate change presents a significant threat to our economic future." ${ }^{204}$ Another 72 percent agreed that "the science of climate change is irrefutable"; 79 percent believed "Canada's international reputation has been hurt by its previous efforts"; and 63 percent indicated that they "would pay more for certain products so Canada could meet its climate commitments." 205

More recently, in a survey of 1,000 Canadians conducted by Nanos Research for Clean Energy Canada, 77 percent of Canadians supported or somewhat supported "a national plan that ensures Canada achieves its international climate change targets to reduce carbon emissions." ${ }^{206}$ Moreover, 62 percent of respondents supported or somewhat supported "a minimum carbon price that applies across Canada." ${ }^{207}$ And 66 percent of respondents agreed or somewhat agreed that "it is more important to have a plan to meet Canada's climate change targets than to have all provincial and territorial premiers agree with that plan."208 According to pollster Nik Nanos: "[ $\mathrm{t}]$ he appetite to move forward on environmental issues is quite strong - whether it be strong leadership by the Government of Canada to make sure Canada meets its climate targets, or carbon pricing." 209

Most recently as of this writing, in a poll of 1,500 Canadians conducted by Abacus Data, 86 percent of respondents - including majorities in each geographic region of Canada supported a plan to "shift Canada's energy use over the coming decades, including incentives to promote cleaner transportation and buildings, and pricing carbon to encourage a shift towards greater use of cleaner energy." ${ }^{210}$ Canadians certainly appear to be exceptionally attentive to issues around climate change and sustainability. How is the government responding?

\section{Climate Change Policy’s NeW “Sunny Ways”}

The federal Liberal party — and now federal government - certainly appears to have heard Canadians. On climate change, its 2015 election platform promised to "provide national leadership and join with the provinces and territories to take action on climate

Ibid.

Campbell Clark, "Canadians Back Bold Climate-Change Action, Poll Finds," The Globe and Mail (27 November 2015), online: <https://www.theglobeandmail.com/news/politics/canadians-back-boldclimate-change-action-poll-finds/article27518927/>.

Ibid.

Merran Smith, "Poll: Most Canadians Want Federal Leadership on Climate Change," Clean Energy Canada (2 October 2016), online: <cleanenergycanada.org/poll-canadians-want-federal-leadershipclimate-change/>.

Ibid.

Ibid.

Ibid.

Bruce Anderson \& David Coletto, "Climate, Carbon, and Pipelines: A Path to Consensus?," Abacus Data (18 October 2016), online: <abacusdata.ca/climate-carbon-and-pipelines-a-path-to-consensus/> [emphasis in original]. 
change, put a price on carbon, and reduce carbon pollution." ${ }^{211}$ Regarding the government's environmental assessment processes, the Liberal platform recognized that "Canadians must be able to trust that government will engage in appropriate regulatory oversight, including credible environmental assessments." ${ }^{212}$ To restore Canadians' trust in those processes, which are critical to ensuring that Canada can deliver on its climate change commitments and its promise of a "New Nation-to-Nation Process" between Canada and Indigenous peoples, ${ }^{213}$ the party's platform promised, among other things, to "provide ways for Canadians to express their views and opportunities for experts to meaningfully participate." ${ }^{214}$ As the platform notably added, "[w] hile governments grant permits for resource development, only communities can grant permission." 215

In order to give effect to these commitments, during its first year in office the federal government launched a public consultation process ostensibly modelled on the CRTC's popular "Let's Talk TV" initiative, branding it "Let's Talk Climate Action." ${ }^{\text {"16 }}$ According to the initiative's "Activity Scorecard," the government received 10,177 comments and 3,462 ideas from 4,045 participants. ${ }^{217}$ Commenced in April 2016, participants' comments and ideas ${ }^{218}$ were collected and categorized by theme, presumably for ease of reference and use by the working groups created by the government to create its national climate change plan. Specifically, the government pre-established working groups to address the following four issues: (1) "[h]ow and where to reduce emissions"; (2) "[c]lean technology, innovation and job creation"; (3) "[h]ow to prepare for the impacts of a changing climate"; and (4) "[p]utting a price on carbon." ${ }^{219}$

In concert with its "Let's Talk Climate Action" initiative the Liberal government commenced a comprehensive review of its environmental assessment processes. ${ }^{220}$ In addition, pursuant to interim measures for reviewing oil pipeline proposals adopted in

211 Liberal Party of Canada, "Climate Change," online: $<$ https://www.liberal.ca/realchange/climatechange/> [emphasis in original]. This was an important plank in the Liberals' promise of a new, "sunny ways" approach to federal politics. See Mark Gollom, "Justin Trudeau Pledges 'Real Change' as Liberals Leap Ahead to Majority Government," CBC News (20 October 2015), online: <www.cbc.ca/ news/politics/canada-election-2015-voting-results-polls-1.3278537>. The phrase was coined, however, by former Liberal Prime Minister Sir Wilfred Laurier: “Justin Trudeau's 'Sunny Ways' a Nod to Sir Wilfred Laurier," CBC News (20 October 2015), online: <www.cbc.ca/news/canada/nova-scotia/ns-proftrudeau-sunny-ways-1.3280693>.

Liberal Party of Canada, "Environmental Assessments," online: <https://www.liberal.ca/realchange/ environmental-assessments/>.

Liberal Party of Canada, "A New Nation-To-Nation Process," supra note 180.

Liberal Party of Canada, "Environmental Assessments," supra note 212.

Ibid [emphasis added]. See also Government of Canada, "Environmental and Regulatory Reviews: Discussion Paper" (June 2017), online: <https://www.canada.ca/content/dam/themes/environment/ conservation/environmental-reviews/share-your-views/proposed-approach/discussion-paper-june-2017eng.pdf $>$.

Government of Canada, "Let's Talk Climate Action," online: <https://web.archive.org/web/20161013 $042847 / \mathrm{http}: / /$ letstalkclimateaction.ca/ideas $>$. As of this writing, the interactive online initiative had closed: "Thank you Canada! The deadline for submitting ideas has now passed. You can keep the conversation going on social media using the \#CANClimateAction hashtag" (ibid.) See also the Twitter page for \#CANClimateAction, online: $<$ https://twitter.com/search?q=\%23CANclimateaction>. Ibid.

This distinction is not defined by the government (ibid).

Government of Canada, "Canada's Approach to Climate Change," online: <https://web.archive.org/web/ 20161114093951/http://letstalkclimateaction.ca/canada-s-approach-to-climate-change> .

Government of Canada, "Review of Environmental Assessment Processes" (20 June 2016), online: $<$ https://web.archive.org/web/20160621113540/news.gc.ca/web/article-en.do?nid=1088149> [Government of Canada, "Review of Environmental Assessment Processes"]. The review remains ongoing as of this writing. For further details see the government's environmental assessment review panel's website, online: <https://web.archive.org/web/20161114233558/http://eareview-examenee.ca/ participate/>. 
February $2016,{ }^{221}$ the government struck an expert panel to carry out a supplemental review of Kinder Morgan's Trans Mountain oil pipeline proposal, ${ }^{222}$ despite the National Energy Board having recommended that Cabinet approve the project subject to 157 technical conditions in the spring of $2016 .{ }^{223}$ The government also reviewed applications for permits necessary to continue construction of the CDN\$9 billion Site C hydroelectric power dam project in northeastern British Columbia, ${ }^{224}$ and completed the environmental assessment of the controversial Pacific Northwest LNG proposal. ${ }^{225}$ The government summed up its climate change policymaking approach thus: "[p]rovincial, territorial and federal governments are working together with Indigenous Peoples and the public to find ways to encourage clean economic growth, reduce greenhouse gas emissions and prepare for the impacts of climate change." 226

\section{WALKing THE Climate TAlK, OR SUNNY WAYS TALKING POINTS?}

How does one assess the federal government's approach to climate policymaking, which certainly bears the formal trappings of a new, aspirational federalism? Leaving aside for the moment the nature of the consultations, by the fall of 2016 the government began to issue initial decisions on natural resource development projects having significant climate change and sustainability implications along with the key planks of its emerging national climate policy.

The first such decision was the federal government's quiet approval of two permits necessary for the continuation of the construction of the Site C hydroelectric power dam in northeastern British Columbia. ${ }^{27}$ The reaction of affected First Nations along with environmentalists and academics, however, was anything but quiet. ${ }^{228}$ Two First Nations West Moberly First Nation and Prophet River First Nation — immediately commenced a legal challenge against the government's issuance of the permits in Federal Court. ${ }^{229}$ The First Nations argued that the 1,100-megawatt dam on the Peace River, which will flood approximately 5,500 hectares of land, violates Aboriginal rights to hunt, fish, and collect

Government of Canada, "Interim Measures for Pipeline Reviews" (27 January 2016), online: <https:// www.canada.ca/en/natural-resources-canada/news/2016/01/interim-measures-for-pipelinereviews.html>. See also Jason MacLean, "How to Evaluate Energy East? Try Evidence," Toronto Star (7 February 2016), online: <https://www.thestar.com/opinion/commentary/2016/02/07/how-to-evaluateenergy-east-try-evidence.html>. Ibid.

National Energy Board, "Summary of Recommendation - Trans Mountain Expansion Project" (27 February 2017), online: <www.neb-one.gc.ca/pplctnflng/mjrpp/trnsmntnxpnsn/smmrrcmmndtn-eng. $\mathrm{html}>$ [National Energy Board, "Summary of Recommendation"].

See Betsy Trumpener, "Trudeau Government Signals Support for Site C Dam, Grants Two Permits," CBC News (29 July 2016), online: <www.cbc.ca/news/canada/british-columbia/trudeau-governmentissues-key-federal-permits-for-site-c-1.3700880>.

Government of Canada, News Release, "The Government of Canada Approves Pacific Northwest LNG Project" (27 September 2016), online: <https://www.canada.ca/en/environmental-assessment-agency/ news/2016/09/government-canada-approves-pacific-northwest-project.html $>$ [Government of Canada, "Canada Approves Pacific Northwest LNG"].

Liberal Party of Canada, "Government Consultations," online: <renfrewnipissingpembroke.liberal.ca/ government-consultations/>.

Carol Linnitt, "Trudeau Silent as B.C. First Nations Take Site C Dam Fight to Federal Court," The Narwhal (13 September 2016), online: $<$ https://www.thenarwhal.ca/trudeau-silent-bc-first-nations-takesite-c-dam-fight-federal-court> [Linnitt, "Trudeau Silent"].

See e.g. Emma Gilchrist, "Trudeau Just Broke his Promise to Canada's First Nations," The Narwhal (29 July 2016), online: $<$ https://www.thenarwhal.ca/trudeau-just-broke-his-promise-canada-s-first-nations $>$. Linnitt, "Trudeau Silent," supra note 227. 
medicinal plants on what is Treaty 8 territory. The First Nations further relied on the findings of a joint federal-provincial environmental assessment, concluding that the project will result in significant and irreversible environmental impacts, but which was unable to conclude that the power from Site $\mathrm{C}$ was actually necessary on the schedule provided by B.C. Hydro. ${ }^{230}$

Moreover, the project has been characterized as the most environmentally destructive project ever considered under the Canadian Environmental Assessment Act. ${ }^{231}$ In a public "Statement of Concern," 250 scientists and academics urged the British Columbia government to direct the B.C. Utilities Commission to conduct a comprehensive review of the project, echoing a recommendation of the joint environmental assessment panel. The British Columbia Liberal government refused and the project proceeded. ${ }^{232}$

Making the government's issuance of the permits all the more controversial was the recently surfaced remarks made by federal Minister of Justice Jody Wilson-Rayboud, who in 2012 observed that

[t]he country's reputation is at stake with approval of these projects like Site C, like the Enbridge pipeline.... Our reputation as a caring and considerate environmentally friendly nation internationally is going to be questioned. Running roughshod over aboriginal treaty and rights, including treaty rights, is not the way to improve that reputation. $^{233}$

Next was the government's decision to approve — subject to 190 technical (and mainly toothless) conditions — the CDN\$36 billion Pacific NorthWest LNG project in British Columbia. ${ }^{234}$ The project involved the construction of two pipelines to carry shale gas from northeastern British Columbia to an CDN\$11.4-billion LNG terminal to be constructed on the Pacific coast with an estimated operational lifespan of 30 years; from the terminal approximately 19 million tonnes of liquefied natural gas will be exported to Asian markets. In issuing its decision, the government reiterated its key policy commitments, noting that (1) the "[v]iews of the public and affected communities were sought and considered," (2) "Indigenous peoples were meaningfully consulted, and where appropriate, impacts on their rights and interests were accommodated," (3) the decision was based on science and the traditional knowledge of Indigenous peoples, and (4) direct and upstream GHG emissions

Review Panel Established by the Federal Minister of the Environment and the British Columbia Minister of the Environment, Report of the Joint Review Panel: Site C Clean Energy Project BC Hydro (Ottawa: Government of Canada, 2014) at 307-308, online: <https:/www.ceaa-acee.gc.ca/050/documents/ p63919/99173E.pdf>. See also Judith Lavoie, "Anxious Communities Still Without Answer on Fate of Site C Mega-dam After JPR Report Release” The Narwhal (8 May 2014), online: <https://www. thenarwhal.ca/communities-without-answer-fate-site-c-after-jrp-report>.

Judith Lavoie, "Site C Not Subject to 'Rigorous Scrutiny,' Fails First Nations, Royal Society of Canada Warns Trudeau," The Narwhal (24 May 2016), quoting Professor Karen Bakker, Canada Research Chair in Water Governance at the University of British Columbia, online: $<$ https://www.thenarwhal.ca/site-cnot-subject-rigorous-scrutiny-fails-first-nations-royal-society-canada-warns-trudeau $>$. Ibid. See also "Site C: Statement by Concerned Scholars," online: $<$ https://web.archive.org/web/201702 15234430/https://sitecstatement.org/>. However, the NDP provincial government, elected during the summer of 2017, directed the British Columbia Utilities Commission to review and reassess the project. See Mike Hager, "B.C. NDP Asks Independent Panel to Decide Fate of Site C Dam Project," The Globe and Mail (2 August 2017), online: <https://www.theglobeandmail.com/news/british-columbia/bc-asksutilities-commission-to-review-88-billion-site-c-dam-megaproject/article35870031/>. (23 March 2016), online: <https://www.theglobeandmail.com/news/british-columbia/site-c-criticism-byfederal-justice-minister-surfaces-in-2012-video/article29374893/> [emphasis added]. 
linked to the project were assessed. ${ }^{235}$ The Canadian Environmental Assessment Agency's report concluded, however, that the project will cause GHG emissions (approximately four million tonnes per year, and perhaps twice that amount in upstream emissions) that are "high in magnitude, continuous, irreversible and global in extent." 236 The project - had it ultimately proceeded - may well have become the largest source of carbon pollution in Canada. ${ }^{237}$ The federal Cabinet concluded, however, that in accordance with paragraph 52(4)(a) of the CEAA, 2012, "the significant adverse environmental effects that the Designated Project is likely to cause are justified in the circumstances." 238

Environmental and First Nations advocates did not agree and responded critically and emotionally to the government's announcement. Donnie Wesley, described as the highestranking hereditary chief of the Gitwilgyoots tribe, which claims jurisdiction over Lelu Island where the LNG terminal would be built, called Prime Minister Trudeau "an outright liar" and said the project's approval was "a slap in the face." ${ }^{239}$ A spokesperson for Sierra Club British Columbia similarly characterized the government's approval of the LNG project as a "betrayal to the many who voted for action on climate change.... The Trudeau government's lofty rhetoric on climate has been proven nothing more than sunny ways talking points."240

First Nations and environmental organizations immediately signaled their intention to seek judicial review of the government's decision, which they argue ignored both the adverse impacts on wild salmon in the Skeena River, British Columbia's second-longest salmonbearing river, as well as the magnitude and cumulative effects of the project's estimated GHG emissions on climate change. ${ }^{241}$ Indeed, the decision drew international recognition, with The Guardian newspaper in the United Kingdom reporting that "Canada's commitment to fighting climate change has been questioned after the Liberal government, led by Justin Trudeau, announced conditional approval for a C\$36bn liquefied natural gas project in northern British Columbia."242

Ibid [emphasis omitted].

Canadian Environmental Assessment Agency, Pacific NorthWest LNG Project: Environmental Assessment Report (Ottawa: CEAA, September 2016) at 43, online: <www.ceaa.gc.ca/050/documenteng.cfm? document $=115668>$.

Ibid at 41. See also the open letter dated 26 May 2016 from 90 international climate change scientists and climate policy experts urging the government to reject the project "due to its significant adverse environmental effects from greenhouse gas (GHG) emissions" (Letter from International Climate Change Scientists and Climate Policy Experts to Catherine McKenna, Minister of Environment and Climate Change (26 May 2016), online: <https://www.scribd.com/document/314292821/ClimateScientists-Letter-to-Federal-Government>).

Canadian Environmental Assessment Agency, "Decision Statement Issued under Section 54 of the Canadian Environmental Assessment Act, 2012 (Ottawa: CEAA, 2016) at 2, online: <www.ceaa.gc.ca/ 050/document-eng.cfm?document $=115669>$ [emphasis added].

Hilary Beaumont, "First Nation Groups Launching Massive Lawsuit After Trudeau's LNG Decision," VICE (29 September 2016), online: <https://www.vice.com/en_ca/read/first-nations-groups-launchingmassive-lawsuit-after-trudeaus-lng-decision>.

Ashifa Kassam, "Environmentalists 'Expected Better' of Trudeau as Canada Backs Gas Projects," The Guardian (28 September 2016), online: < https://www.theguardian.com/world/2016/sep/28/canadapacific-northwest-lng-natural-gas-pipeline-british-columbia $>$.

Jason MacLean \& Chris Tollefson, "Climate-Proofing Judicial Review After Paris: Judicial Competence, Capacity, and Courage," 31:3 J Envtl L \& Prac [forthcoming in 2018].

Kassam, supra note 240. Note, however, that the project's principal proponent ultimately decided during the summer of 2017 not to proceed with construction. See Jeffrey Jones, "Halt to \$11.4-Billion LNG Project Dims Canada's Export Hopes," The Globe and Mail (25 July 2017), online: <https://www.the globeandmail.com/report-on-business/malaysias-petronas-scraps-114-billion-pacific-northwest-lngproject-in-bc/article35790713/>. 
Just days after its approval of Pacific NorthWest LNG, however, the government announced the key plank of its pan-Canadian climate change policy - a national price on carbon beginning in 2018, with or without provincial and territorial cooperation. ${ }^{243}$ The proposed plan is simple on its face: beginning in 2018 there will be national price on carbon of at least CDN\$10 per tonne, which will rise by CDN\$10 per year until 2022 when the price will reach CDN\$50 per tonne, whereupon the price will be reviewed - and presumably raised - as part of the Paris Agreement's iterative global stocktake. Provinces have the choice of implementing either a carbon tax (for example, British Columbia and Alberta) or a cap-and-trade regime (for example, Quebec and Ontario) in order to price carbon, with all revenues returning to the source province, making the policy revenue neutral with respect to the federal government. ${ }^{244}$

The government announced its carbon pricing policy - which was adumbrated in the Vancouver Declaration ${ }^{245}$ — as it tabled a motion to ratify the Paris climate change agreement and Canada's target of a 30 percent reduction in its GHG emissions from 2005 levels by 2030 for debate and a vote in the House of Commons. ${ }^{246}$ The government further explained that it would complement its pan-Canadian carbon price with a range of both command-and-control and flexible energy efficiency regulations in respect of transportation as well as commercial and residential buildings. ${ }^{247}$

Remarkably soon thereafter, however, the federal government announced its approval of Kinder Morgan's controversial expansion of the Trans Mountain pipeline. ${ }^{248}$ Kinder Morgan will twin the existing pipeline running from Edmonton, Alberta to Burnaby, British Columbia, effectively tripling its capacity to 890,000 barrels per day of diluted bitumen from Alberta's oil sands. ${ }^{249}$ According to the federal Ministry of the Environment and Climate

Government of Canada, News Release, "Government of Canada Announces Pan-Canadian Pricing on Carbon Pollution" (3 October 2016), online: $<$ https://www.canada.ca/en/environment-climate-change/ news/2016/10/government-canada-announces-canadian-pricing-carbon-pollution.html $>$.

Ibid. Logistical details about how the federal government will return revenues to provinces in applicable jurisdictions, and where the province's own effective price is below that of the government's national price, are not known as of this writing, but see Andrew Leach, "The Challenges Ahead for Liberals' Carbon Plan," The Globe and Mail (6 October 2016), online: <https://www.theglobeandmail.com/ opinion/the-challenges-ahead-for-liberals-carbon-plan/article32266670/>.

Canadian Intergovernmental Conference Secretariat, "Vancouver Declaration," supra note 161.

See Shawn McCarthy, "Liberal Government Formally Ratifies Paris Climate Accord," The Globe and Mail (5 October 2016), online: <https:/www.theglobeandmail.com/news/politics/ottawa-formallyratifies-paris-climate-accord/article32267242/ $>$. It is important to note that the government introduced its motion regarding the Paris Agreement and its carbon-pricing plan in Parliament while, at the same time in Montreal, the Minister of the Environment and Climate Change was in a meeting with her provincial and territorial counterparts discussing the pros and cons of the very policy simultaneously being announced by the Prime Minister as a fait accompli: Bruce Cheadle, "Sask., N.S. and N.L. Ministers Walk Out of Climate Talks After Trudeau Announces Carbon Price," CBC News (3 October 2016), online: <www.cbc.ca/news/politics/federal-provincial-environment-ministers-meeting-1.378 9134>.

See Michelle Zilio, "Ottawa to Roll Out New Rules to Cut Canadian Carbon Emissions," The Globe and Mail (9 October 2016), online: < https://beta.theglobeandmail.com/news/politics/ottawa-to-roll-out-newrules-to-cut-canadian-carbon-emissions/article32312495/>. For example, incentives for home-energy retrofits and phased-in changes to the national building code standard: see e.g. Shawn McCarthy, "Ottawa Set to Re-Introduce Incentives for Home-Energy Retrofits," The Globe and Mail (18 October 2016), online: <https://web.archive.org/web/20161110124010/https://www.theglobeandmail.com/reporton-business/industry-news/energy-and-resources/ottawa-to-incentivize-energy-efficient-homeretrofits/article32429370/>.

John Paul Tasker, "Trudeau Cabinet Approves Trans Mountain, Line 3 Pipelines, Rejects Northern Gateway," CBC News (29 November 2016), online: <www.cbc.ca/news/politics/federal-cabinet-trudeaupipeline-decisions-1.3872828>. Ibid. 
Change, once fully operational at capacity, the expanded Trans Mountain pipeline may contribute upstream GHG emissions of 20-26 megatonnes of carbon dioxide per year of its operation. ${ }^{250}$ Notwithstanding his government's own GHG emissions estimates for Trans Mountain, the Prime Minister insisted that Canada is still a "climate leader." 251 Once again, however, advocates of environmental protection and Indigenous rights disagreed, and commenced legal proceedings contesting the government's approval. ${ }^{252}$

\section{Aspirational Climate Federalism, OR LET'S TALK CLIMATE CONTRADICTION?}

All of which leads to the critical question pursued in this article: are the federal government's policy proposals and initial climate related decisions capable of vindicating its commitments under the Paris Agreement and its own lofty promises of a democraticallyenhanced mode of environmental governance, which I have termed for analytic purposes federalism 3.0?

Macdonald and Wolfe considered a carbon tax to be an ideal illustration of aspirational social-cum-fiscal federal policy. ${ }^{253}$ They argued that for demand-driven government programs to succeed, governments must provide citizens with the information and wherewithal they need to make their own meaningful choices. But this, they argued, "often requires embedding information in the tool." ${ }^{254}$ Unlike consumption taxes, which convey only the general and undifferentiated information that consumption attracts more tax than saving, "a visible, point-of-sale carbon tax is information rich. Climate-change policy could therefore be based not on top-down regulation or large bureaucracies but on price signals that convey information to citizens about their choices" and "help citizens as consumers make environmentally aware decisions." ${ }^{255}$ Regulatory instruments, no matter how flexible and information-rich, are "significantly less respectful of citizen autonomy." 256

This estimate does not account, however, for the vast majority of GHG emissions associated with the pipeline's expansion, which will be emitted downstream in export markets where the oil reaches its ultimate destination and is combusted: Environment and Climate Change Canada, "Trans Mountain Pipeline ULC - Trans Mountain Expansion Project: Review of Related Upstream Greenhouse Gas Emissions Estimates" (Ottawa: ECCC, 2016) at 5.

Tasker, supra note 248. But see Chris Tollefson \& Jason MacLean, "Here is Why B.C. Must Do its Own Review of the Trans Mountain Pipeline," The Globe and Mail (23 May 2017), online: <https://beta.the globeandmail.com/opinion/why-bc-must-do-its-own-review-of-the-trans-mountain-pipeline/ article35095482/>.

See e.g. Bruce Cheadle, "Environmentalists File Court Challenge of Ottawa's Trans Mountain Pipeline Approval," CBC News (20 December 2016), online: <www.cbc.ca/news/canada/calgary/pipelineswhales-british-columbia-lawsuit-noise-trans-mountain-calgary-court-1.3904797>; Geordon Omand, "Trans Mountain Pipeline Project Facing New Legal Challenges From First Nations," The Canadian Press (17 January 2017), online: <https://globalnews.ca/news/3187421/first-nations-take-crown-tocourt-over-pipeline/>. The recently elected British Columbia NDP government sought and secured intervener status in the consolidated proceeding before the Federal Court of Appeal: Tsleil-Waututh Nation v Canada (AG), 2017 FCA 174, 414 DLR (4th) 373.

253 Macdonald \& Wolfe, supra note 159 at 509. See also Michael Wara, "Instrument Choice, Carbon Emissions, and Information" (2015) 4:2 Michigan J Environmental \& Administrative L 261.

$254 \quad$ Macdonald \& Wolfe, ibid at 507.

255 Ibid at 509 [emphasis added]. Similarly, The Economist puts it this way: "[Ask] an economist how best to reduce pollution, and the chances are that they will recommend taxing carbon emissions. And with good reason: doing so should encourage markets to find the least costly way to reduce pollution, something governments will struggle discover themselves" "Of Wood and Trees" The Economist (13 October 2016), online: $<$ https://www.economist.com/news/united-states/21708684-environmentalistsagainst-environment-evergreen-state-wood-and-trees $>$ ). 
What signal does the government's evolving climate change policies and decisions send to Canadians? Beginning with the pan-Canadian price on carbon - starting at $\$ 10$ per tonne in 2018 and rising to $\$ 50$ per tonne by 2022 — the government is signaling that, while it wants to appear to be taking serious and timely action on climate change, it is not yet prepared to do so. The government's carbon price proposal suffers from three fundamental - yet fixable - flaws. ${ }^{257}$

First, the price is too low to matter. While any price on carbon will reduce emissions, the government's proposed price is too low to help Canada meet its already insufficiently ambitious GHG-reduction target of 30 percent below 2005 levels by 2030. To play a meaningful role in meeting our escalating obligations under the Paris Agreement, the price must approximate the true externalized social cost of carbon, or the monetized damage of emitting one tonne of $\mathrm{CO}_{2}$ into the atmosphere. ${ }^{258}$ Estimates vary, but that cost is likely between US\$50 and US\$220 per tonne. ${ }^{259}$ For example, a recent analysis of Canada's GHG reduction target found that an effective pan-Canadian price on carbon would need to start at CDN\$30 per tonne and increase CDN\$15 annually to a price of CDN\$200 per tonne by $2030 .{ }^{260}$ Even if supplemented by a suite of flexible — but not cost-free - sectoral energy efficiency regulations bearing an implicit carbon price, the explicit carbon price would still need to be significantly higher, and significantly sooner, than the government's present policy. ${ }^{261}$

Second, the government's policy is puzzlingly paradoxical. It appears to be designed, not to rapidly reduce GHG emissions in line with the Paris Agreement, but rather to facilitate further oil and gas extraction in Canada. For years oil and gas projects wanted for both legal and social license due to the Harper government's failure to impose regulations on the sector. But the imposition of a price on carbon, even one as patently ineffective as the Trudeau government's proposed price, provides potential political "cover for otherwise unsustainable and unjustifiable oil and gas projects to proceed." 262 Indeed, while the timing of the government's announcement of its carbon price proposal rankled certain provinces

See e.g. Jason MacLean, “Trudeau's Carbon Price Clever Politics, Not Credible Climate Policy,” Policy Options (14 October 2016), online: < policyoptions.irpp.org/magazines/october-2016/trudeaus-carbonprice-clever-politics-not-credible-climate-policy/> [MacLean, "Trudeau's Carbon Price"]. See also Mark Jaccard, "Penny Wise and Pound Foolish on Climate Policy?," Policy Options (11 October 2016), online: <policyoptions.irpp.org/magazines/october-2016/penny-wise-and-pound-foolish-on-climatepolicy/>; Trevor Tombe, "Put a Price on Emissions and Let the Chips Fall Where They May," Maclean's (3 October 2016), online: <www.macleans.ca/economy/economicanalysis/put-a-price-onemissions-and-let-the-chips-fall-where-they-may/>; Leach, supra note 244.

See e.g. Inge van den Bijgaart, Reyer Gerlagh \& Matti Liski, "A Simple Formula for the Social Cost of Carbon" (2016) 77 J Environmental Economics \& Management 75.

See e.g. JCJM van den Bergh \& WJW Botzen, "A Lower Bound to the Social Cost of $\mathrm{CO}_{2}$ Emissions" (2014) 4 Nature Climate Change 253; Frances C Moore \& Delavane B Diaz, "Temperature Impacts on Economic Growth Warrant Stringent Mitigation Policy" (2015) 5 Nature Climate Change 127; Carbon Pricing Leadership Coalition, Report of the High-Level Commission on Carbon Pricing (Washington, DC: World Bank, 2017), online: <https://www.carbonpricingleadership.org/report-of-the-highlevelcommission-on-carbon-prices> Its Paris Commitment ... and Get Re-Elected?" (2016) School of Resource and Environmental Management, Simon Fraser University at 23, online: $<$ rem-main.rem.sfu.ca/papers/jaccard/Jaccard-HeinVass\%20CdnClimatePol\%20EMRG-REM-SFU\%20Sep\%2020\%202016.pdf\$. 
(Newfoundland and Labrador, Nova Scotia, and Saskatchewan in particular), ${ }^{263}$ the timing may well have been politically strategic. Recall that the announcement followed closely on the heels of the government's controversial decision to approve the Pacific NorthWest LNG project, despite its significant GHG emissions. The timing of the government's carbon price announcement, along with its rushed ratification of the Paris Agreement before the government had even finalized its climate change policy, may well have been chosen to help legitimize its LNG decision while seeking to reassure domestic and international stakeholders that Canada remains committed to combatting climate change. ${ }^{264}$

Moreover, the timing of the announcement may also have been designed to help legitimize the government's then anticipated (and soon-after-consummated) approval of the equally controversial Trans Mountain pipeline expansion. As explained above, the approved expansion would triple the pipeline's capacity to carry bitumen crude oil from Alberta's oil sands to the coast of British Columbia and international markets beyond. ${ }^{265}$ The proposed expansion, however, would also significantly increase Canada's GHG emissions. ${ }^{266}$

This suggestion is not mere speculation. Consider the following representations made by senior Cabinet members of the federal government, beginning with the "flip-flop" in the government's definition of "social license" in respect of the approval of natural resources projects like Trans Mountain that are opposed by local communities, among others. ${ }^{267}$ As noted above, in its federal election campaign platform, the Liberals proclaimed: "[w]hile governments grant permits for resource development, only communities can grant permission." 268 Many communities, including the municipalities of Burnaby and Vancouver, took that campaign promise to mean that communities will have a strong say in - if not an outright veto over - natural resources projects involving significant adverse environmental impacts in their jurisdictions. After less than a year in office, however, the office of Natural Resources Minister Jim Carr noted in response to formal questions tabled by the New Democratic Party Member of Parliament for Burnaby South that the goal of reviews of natural resource projects is to "provide regulatory certainty not only to project proponents, so they know the basis on which decisions will be made, but also to the public, so they know that the environment will be protected and that economic growth will be based on proper

See The Canadian Press, "After Sask., Nova Scotia, N\&L Ministers Walk Out on Meetings, N.S. Premier Says Province 'Will Not be Implementing a Carbon Tax," Saskatoon StarPhoenix (4 October 2016), online: $<$ thestarphoenix.com/news/local-news/after-sask-nova-scotia-nl-ministers-walk-out-onmeetings-n-s-premier-says-province-will-not-be-implementing-a-carbon-tax $>$.

MacLean, "Trudeau's Carbon Price," supra note 257.

National Energy Board, "Summary of Recommendation," supra note 223.

Indeed, over the expected and locked-in 50-year lifespan of the pipeline, its associated upstream GHG emissions would constitute up to 83 percent of Canada's share of the Paris Agreement carbon budget under the $2^{\circ} \mathrm{C}$ limit, and 100 percent of its share under the $1.5^{\circ} \mathrm{C}$ limit (Simon Donner, "Statement on Greenhouse Gas Emissions Associated with the Trans Mountain Pipeline Expansion" (17 August 2016) Maribo (blog), online: <blogs.ubc.ca/maribo/2016/08/17/statement-on-greenhouse-gas-emissionsassociated-with-the-trans-mountain-pipeline-expansion/>.

For example, the municipalities of Burnaby, British Columbia, and Vancouver, British Columbia, are opposed to the Trans Mountain pipeline expansion and have commenced litigation in opposition to it. Other local communities and First Nations are also opposed to the project. As of this writing, a consolidated judicial review of the government's approval of the project is pending before the Federal Court of Appeal: Tsleil-Waututh Nation v Canada (Attorney General), Court No A-78-17 (FCA). Liberal Party of Canada, "Environmental Assessments," supra note 212 [emphasis added]. 
oversight, protections and safeguards. ${ }^{269}$ Absent is any mention of community participation, let alone approval.

Even more telling are the remarks made by the Prime Minister himself about critics of his government's carbon price policy. According to the Prime Minister, the price on carbon will "make it more possible than it was for the past 10 years to actually get our resources to market, to perhaps build a pipeline to tidewater." ${ }^{270}$ Later, the Prime Minister misleadingly and irresponsibly dismissed critics of new oil pipelines by remarking that " $[\mathrm{w}]$ here we have to recognize that we're not going to find common ground is in the people who say the only thing we can do to save the planet is to shut down the oil sands tomorrow and stop using fossil fuels altogether within a week," 271 a straw man argument not actually advanced by anyone in Canada. ${ }^{272}$ And most recently as of this writing, the Prime Minister generated considerable controversy in early 2017 when he told an audience of Canadians in Peterborough, Ontario that Alberta's oil sands must be "phased out," only to soon thereafter tell an audience of Canadians gathered in Calgary, Alberta that "I misspoke," adding that only "in about 100 years [will] fossil fuels ... no longer be needed for fuel or energy." 273 So much, then, for the aspirations of the Paris Agreement and a new climate federalism?

Hence the paradoxical nature — the mixed signals — of the government's proposed carbon price: while the purpose of imposing an escalating price on carbon is to phase out as soon as possible carbon emissions and the industries most responsible for those emissions, the government's proposed price is more akin to a subsidy than a price, more an incentive than a penalty. ${ }^{274}$

Which leads to the third and most perverse flaw of the government's carbon-price policy - the persistence of actual subsidies to the oil and gas sector. According to the United Nations Climate Change Secretariat, fossil fuels subsidies, be they direct government transfers of money or tax benefits, "encourage investment in fossil fuel extraction, processing and consumption." 275 Imposing a price on carbon while refusing to eliminate subsidies to the fossil fuels industry is not unlike raising the tax on cigarettes while giving tobacco

Quoted in Peter O’Neil, “Federal Government's 'Social Licence' for Pipelines 'Permission' Cuts Out Communities," Vancouver Sun (21 September 2016), online: <vancouversun.com/news/local-news/ federal-governments-social-licence-for-pipelines-permission-cuts-out-communities $>$.

Quoted in The Canadian Press, "Trudeau Says Naysayers on Canada's Carbon-Tax Plan using 'Scare Tactics," "CBC News (14 October 2016), online: <www.cbc.ca/news/canada/calgary/trudeau-carbon-taxscare-tactics-1.3805715> [emphasis added]. 271 Quoted in Ian Bailey, “Trudeau Resolute on Trans Mountain Pipeline Expansion Despite Protests," The
Globe and Mail (20 December 2016), online: < https://www.theglobeandmail.com/news/britishcolumbia/trudeau-resolute-on-trans-mountain-pipeline-expansion-despite-expected-protests/ article33397590/>.

272 Emma Gilchrist, "Trudeau's New Pipeline Talking Point — Straight From the Oil Industry,” The Narwhal (21 December 2016), online: <https://www.thenarwhal.ca/trudeau-s-new-pipeline-talkingpoint-straight-oil-industry> (observing that "I've never once come across a single environmentalist who has taken that position").

273 Bill Curry, "Trudeau Says he 'Misspoke' About Phasing Out Oil Sands," The Globe and Mail (24 January 2017), online: <https://www.theglobeandmail.com/news/politics/trudeau-says-he-misspokeabout-phasing-out-oil-sands/article33748712/>.

274 MacLean, "Trudeau's Carbon Price," supra note 257; see also Jason MacLean, "No, Carbon Pricing Alone Won't Be Enough to Lower Emissions," Maclean's (29 November 2016), online: $<$ www.macleans.ca/economy/economicanalysis/no-carbon-pricing-alone-wont-be-enough-to-loweremissions/>.

275 United Nations Climate Change Secretariat, Climate Action Now: Summary for Policymakers 2016 (Bonn, Germany: UNCCS, 2016) at 34, online: <climateaction2020.unfccc.int/spm/spm-archive/>. 
companies cash payouts and tax exemptions to produce and market more cigarettes. ${ }^{276} \mathrm{In}$ 2009, the G20 committed to eliminating fossil fuels subsidies. ${ }^{277}$ In 2015 , the Liberal party's campaign platform promised that "[w]e will fulfill Canada's G-20 commitment to phase out subsidies for the fossil fuel industry. ${ }^{278}$ But in the Trudeau government's first budget, hailed as "the greenest budget ever," 279 the government actually locked in LNG subsidies until 2025 , and otherwise refused to eliminate subsidies to the oil and gas sector, which in recent years have surpassed CDN\$3 billion annually, and which exceed subsidies to the renewable energy sector by a ratio of approximately four to one. ${ }^{280}$ As the Commissioner on the Environment and Sustainable Development concluded in her Fall 2017 Report, "[t]he government does not have a solid strategy for eliminating inefficient fossil fuel subsidies."281

What makes fossil fuel subsidies to the oil and gas sector even more perverse is that the sector's major players arguably do not need them. They have been preparing for the imposition of a price on carbon for years by imposing their own "shadow price" on carbon. Shadow pricing is an investment and decision-making tool used by companies to manage their exposure to the risks associated with a carbon constrained future by imposing their own internal, hypothetical surcharges to market prices for goods and services entailing significant carbon emissions. These shadow prices range from US\$15 to US\$68 per tonne, ${ }^{282}$ a further demonstration of the ineffectiveness of the government's proposed carbon price.

While the government likes to trumpet the corporate sector's support for carbon pricing, especially the support of the oil and gas sector, there is no evidence that the sector's major players would support a carbon price that even remotely approaches the true social cost of carbon, which would be well above the sector's average shadow prices. For example, one commentator and former senior Canadian energy executive, Dennis McConaghy, responded to the federal government's carbon price policy by arguing that "a carbon tax, appropriately conditioned, is a necessary condition for a break through on market access."283 What does that mean for the government's carbon price? According to McConaghy, the price should be set at CDN\$30 per tonne, and "would only rise over time to levels that are comparable to what Canada's other major trading partners are imposing on themselves in terms of carbon

MacLean, "Trudeau's Carbon Price," supra note 257.

Jeff Mason \& Darren Ennis, "G20 Agrees on Phase-Out of Fossil Fuel Subsidies," Reuters (25 September 2009), online: <https://www.reuters.com/article/us-g20-energy-idUSTRE58O18U2009 0926>.

Liberal Party of Canada, "Real Change: A New Plan for Canada's Environment and Economy" (August 2015) at 5, online: $<$ https://www.liberal.ca/files/2015/08/A-new-plan-for-Canadas-environmentand-economy.pdf $>$.

MacLean, "Trudeau's Carbon Price," supra note 257.

See International Institute for Sustainable Development, Global Subsidies Initiative, "Unpacking Canada's Fossil Fuel Subsidies: Their Size, Impacts, and What Should Happen Next" (2016), online: $<$ www.iisd.org/faq/ffs/canada/ $>$. See more generally David Coady et al, "How Large Are Global Energy Subsidies?" (2015) International Monetary Fund Fiscal Affairs Department Working Paper No 15/105, online: <https://www.imf.org/external/pubs/ft/wp/2015/wp15105.pdf>.

Fall 2017 Report, supra note 135 at 1 [emphasis added].

This estimate is derived from Adele Morris, "Why the Federal Government Should Shadow Price Carbon," Brookings (13 July 2015), online: <https://www.brookings.edu/blog/planetpolicy/2015/ 07/13/why-the-federal-government-should-shadow-price-carbon/>. See also "Carbon Copy" The Economist (14 December 2013), online: <https://www.economist.com/news/business/21591601-somefirms-are-preparing-carbon-price-would-make-big-difference-carbon-copy $>$ (disclosing that as of 2013 that ExxonMobil internally priced carbon at US\$60 per tonne, BP and Shell US\$40 per tonne, while Microsoft employed a shadow price of US\$6-7 per tonne).

Dennis McConaghy, "The Canadian Right is Failing on Carbon Pricing," Maclean's (20 October 2016), online: <www.macleans.ca/economy/economicanalysis/the-canadian-right-is-failing-on-carbonpricing/> [emphasis added]. 
pricing, explicitly or implicitly." ${ }^{284}$ McConaghy further argued that the government's policy ought to be accompanied by an "[a]cknowledgment that Canada's national carbon targets are fundamentally aspirational, but not enforceable, obligations. ${ }^{" 285}$ Corporate support indeed.

Moreover, oil and gas sector representatives tend to claim that they support a price on carbon because it produces a level competitive playing field in the energy sector. It turns out, however, that the costs of conventional energy production are approximately in line with the costs of generating wind and solar power, which have declined by 61 percent and 82 percent respectively since $2009,{ }^{286}$ despite being substantially under-subsidized by governments. ${ }^{287}$

Nevertheless, the oil and gas industry continues to accept generous government subsidies while decrying public investments in renewable energy. Writing in support of governmentled carbon pricing, Shell Canada's president Michael Crothers recently impugned the wisdom of the US federal government's USD\$2 billion loan to the world's fourth-largest photovoltaic solar farm in California while applauding the Canadian and Albertan governments' CDN\$865 million contribution to Shell's carbon capture and sequestration (CCS) project "Quest,"288 a potential, but far from economically or scientifically established, means of removing carbon emissions from the atmosphere. ${ }^{289}$

These fundamental flaws suggest that the government's carbon price policy is information-poor and fundamentally misleading. As such, it fails to satisfy the normative aspirations of either federalism 3.0 or the Paris Agreement. With respect to the former, the government's proposed explicit carbon price and its promised implicit carbon pricing by way of a portfolio of command and control and flexible energy efficiency regulations fails the NP3 standard " $[\mathrm{w}]$ here an identifiable cost can easily be associated with an identifiable policy, and providers are enabled to compete on cost, both types of instruments, informational and monetary, are more effective." ${ }^{290}$ Regarding the latter, consider the remarks following the coming into force of the Paris Agreement in the Fall of 2016 made by the president of the Marshall Islands, the country that founded the "High Ambition Coalition" joined by Canada during the Agreement's negotiations: "[n]ow we need to now turn our words into action. Without action, the Paris agreement will just be a piece of paper." 291

\footnotetext{
Ibid.

Ibid.

Paul Krugman, "Wind, Sun and Fire," The New York Times (1 February 2016), online: <https://www. nytimes.com/2016/02/01/opinion/wind-sun-and-fire.html>

287 Notwithstanding this disproportionate level of subsidization, renewable energy is now in a position to meet our energy needs. See Mara Prentiss, Energy Revolution: The Physics and the Promise of Efficient Technology (Cambridge, Mass: Harvard University Press, 2015) at 304:

In sum, the total energy demand for the United States is predicted to be constant for approximately the next fifty years. Electricity generated by renewable energy can easily provide 100 percent of the average [if not yet actual] energy consumption of the United States during those next fifty years, virtually eliminating the negative environmental consequences associated with fossil fuel consumption.

Michael Crothers, "Why Carbon Capture is Just as Important as Renewable Energy," The Globe and Mail (9 October 2016), online: < https://www.theglobeandmail.com/report-on-business/rob-commentary/ why-carbon-capture-is-just-as-important-as-renewable-energy/article32311433/>. Pete Smith et al, "Biophysical and Economic Limits to Negative $\mathrm{CO}_{2}$ Emissions" (2016) 6 Nature Climate Change 42.

Macdonald \& Wolfe, supra note 159 at 510.

John Vidal, "Poor Countries Urge Fast Action on Paris Deal to Stop Catastrophic Warming," The Guardian (7 October 2016), online: <https://www.theguardian.com/global-development/2016/oct/07/ poor-countries-urge-fast-action-paris-climate-deal-to-stop-catastrophic-warming $>$ [emphasis added].
} 
Another reading, however, is possible. Recall the poll described above wherein 86 percent of respondents - including majorities in every geographic region of Canada — supported a shift towards greater use of cleaner energy. ${ }^{292}$ After posing this question, the pollsters then asked the following question: "let's imagine that while putting in place these measures to encourage a shift to renewable energy, the federal government also approved a new pipeline to get Canada's oil and gas to new markets, would you strongly support, support, accept, oppose, or strongly oppose such a decision?"293 The results belie a simple, linear accounting of the relationship between aspirational federalism and Canadians' commitment to the aspirations of the Paris Agreement: 41 percent would "support" this proposal, while 35 percent would "accept" it and only 23 percent would "oppose." 294 Based on these figures, which included majority support in every geographic region of Canada, the poll's authors suggested that "there is a path to creating more comprehensive national support, with a blend of carbon pricing, incentives to promote a shift in energy use, and adding pipeline capacity to get Canada's oil to markets while a shift towards more renewable energy is underway."295 As one commentator observed, "[i]t would be a fair guess that the government has known this for some time - at least as far back as early spring, when Prime Minister Justin Trudeau instructed his team to ensure that at least one of the proposed pipelines [that is, Trans Mountain or Energy East] makes it to salt water." ${ }^{296}$

The early spring of 2016 also coincided with the launch of the government's NP3-style initiative "Let's Talk Climate Action" discussed above. Once again, the timing appears tellingly strategic, with the initiative's invitation to Canadians to share their ideas and take part in a conversation about how to combat climate change effectively providing political cover for a predetermined policy choice to approve one or more major pipeline proposals. When news of the federal government's internal direction to approve at least one pipeline project became public, environmental organizations and climate scientists were understandably nonplussed at this mixed signal regarding the government's public commitments to combat climate change pursuant to the Paris Agreement. Notably, Dr. John Stone, formerly a climatologist with Environment Canada and vice-chair of the UN's Intergovernmental Panel on Climate Change's Working Group II, responded to the news by noting that "[i]f you build a pipeline, you're going to fill it with tar sands that's going to

Anderson \& Coletto, supra note 210.

Ibid at 5 [emphasis in original].

Ibid at 4-5. Note, however, that a poll conducted by EKOS Research Associates in early 2016 found that "[t]hose under the age of 35 are consistently more likely to oppose these [pipeline] proposals, while those ages 65 and over are consistently more supportive" (EKOS Research Associates, "Canadian Attitudes Toward Energy and Pipelines: Survey Findings" (1 March 2016) at 17, online: <www.ekos politics.com/wp-content/uploads/full_report_march_17_2016.pdf $>$ ).

295 Anderson \& Coletto, ibid at 9. See also the results of a recent mid-term poll regarding the performance of the federal government noting that approval of the Trans Mountain pipeline expansion and the imposition of carbon pricing are among the government's most approved of actions to date: Angus Reid Institute, "From Sunny Ways to Midterm Blues? Two Years After Trudeau Majority, Liberals and CPC in Dead Heat," (13 October 2017), online: <angusreid.org/trudeau-midterm/>.

John Ivison, "Liberals' Carbon Pricing Along With Pipeline Approval a Winner With Voters, Poll Suggests," National Post (18 October 2016), online: <news.nationalpost.com/full-comment/john-ivisonliberals-strategy-of-pipeline-approval-with-carbon-pricing-a-winner-with-voters-poll-suggests> [emphasis added]. See also Josh Wingrove, "Trudeau Said to Plan Pipeline Approval, Favor Kinder Morgan," Bloomberg (13 September 2016), online: <https://www.bloomberg.com/news/articles/201609-13/trudeau-said-to-plan-pipeline-approval-favoring-kinder-morgan>; John Ivison, "Trudeau Convinced That Pipeline Strategy Must Be Top Priority," National Post (11 April 2016), online: $<$ news.nationalpost.com/full-comment/john-ivison-trudeau-convinced-that-pipeline-strategy-must-betop-priority>. 
increase our emissions and that's not going to allow us to meet our climate change commitments." ${ }^{, 297}$ Let's talk climate inaction?

Indeed, this alternative reading of the government's policy approach to climate change as being directed toward a "win-win" for the environment and the economy is ultimately untenable. Not only does the government's apparent predetermination regarding pipelines betray its commitment to the Paris Agreement, it further betrays its manifold commitments to NP3-style bidirectional engagement with Canadians. "Let's Talk Climate Action" turns out to be little different than existing e-governance and information technology and communication tools (ICT) employed in environmental assessment processes. ${ }^{298}$ As Sinclair and his colleagues observe in respect of such processes,

[w] hile information sharing through such e-governance is an essential on-ramp to meaningful participation our cases indicate further that sharing has largely been of the monologue form of information-out and that egovernance tools are not being used to promote the sorts of two-way dialogue and deliberation essential to meaningful participation and genuine project betterment through involvement. ${ }^{299}$

The design of the government's Ministerial Panel to hear from Canadians on the Trans Mountain pipeline expansion further illustrates this deficiency of e-governance and ICT as applied to date in Canadian environmental governance. ${ }^{300}$ Natural Resources Canada established an online questionnaire to allow Canadians to make their views on the project known, and also established a three-person panel to review those comments as well as to conduct town halls across Canada. Natural Resources Canada's website announced upon the closing of the questionnaire in early October 2016 that " $[\mathrm{w}] \mathrm{e}$ have received more than 35,000 responses! Thank you to all who participated!"301 Plainly, the panel could not have meaningfully reviewed and considered over 35,000 comments before finalizing its report, which was due to the Minister of Natural Resources on November 1, 2016. Moreover, a truly bidirectional engagement process would have allowed for the review panel's terms of reference to be shaped by public participation. Had that been the case, neither the panel's recommendation nor Cabinet's ultimate decision would have appeared to be quite so predetermined. At a climate forum held following the close of the comment period regarding the Trans Mountain expansion, however, the Minister of Natural Resources remarked that “'[p]eople say, 'Leave the oil in the ground,' they don't want any development.... Our view

Quoted in Charles Mandel \& Mike De Souza, "Trudeau Attacked From All Sides Over Pipeline Stance," National Observer (12 April 2016), online: <https://www.nationalobserver.com/2016/04/12/news/ trudeau-attacked-all-sides-over-pipeline-stance $>$. Dr. Stone's response is anything but an outlier. See generally the climate science literature discussed above in Part II. See e.g. A John Sinclair, Timothy J Peirson-Smith \& Morrissa Boerchers, "The Role of E-Governance and Social Media in Creating Platforms for Meaningful Participation in Environmental Assessment" in Marko M Skoric, Peter Parycek \& Michael Sachs, eds, CeDEM Asia 2014: Conference for E-Democracy and Open Government, (Hong Kong, Edition Donau-Universität Krems, 2015) 139, online: $<$ https://www.donau-uni.ac.at/de/department/gpa/telematik/edemocracy-conference/edem/ $\mathrm{vid} / 20593 /$ index.php?URL=/en/department/gpa/telematik/edemocracy-conference/20593>. Ibid at 146-47 [emphasis added].

This claim is limited to the federal government's use of these tools. For an interesting examination of both the limits and the potential of these tools in other settings, see Cynthia R Farina et al, "Democratic Deliberation in the Wild: The McGill Online Design Studio and the RegulationRoom Project" (2014) 41:5 Fordham Urb LJ 1527.

301 Natural Resources Canada, “Trans Mountain Expansion Project,” online: <https://www.nrcan.gc.ca/ questionnaire/18721>. 
is we use the wealth of the old economy to finance the new energy economy." $" 302$ While a majority of Canadians may ultimately accept this muddled, federalism 2.0 approach, ${ }^{303}$ it is not what they presently aspire to, particularly younger Canadians who will bear a disproportionate burden of the costs and consequences of presently inadequate mitigation efforts. ${ }^{304}$

Nor is the government's climate policymaking approach consistent with its promise of a new, nation-to-nation relationship with Indigenous peoples in Canada. Most recently as of this writing, the Regional Chiefs of the Assembly of First Nations (AFN) publicly announced that it would cease its efforts to collaborate with the federal government on amendments to federal environmental laws, including the CEAA, 2012, ${ }^{305}$ the Fisheries Act, ${ }^{306}$ the Navigation Protection Act, ${ }^{307}$ and the National Energy Board Act. ${ }^{308}$ The AFN cited the federal government's refusal to include the AFN as a partner in the legislative drafting process as the reason for its public break with the government; the federal government claimed that it was precluded from doing so by the requirement of Cabinet confidentiality, a tenuous claim given the participation of the AFN in previous amendments to the Species At Risk Act ${ }^{309}$ through the use of confidentiality agreements. ${ }^{310}$ According to Ontario Regional Chief Isadore Day, "[t]he federal government persists in using the AFN as a top-down, side-door approach to getting consent and that's simply not acceptable. It's simply not right in the eyes of First Nations across Canada or for treaty reasons." 311

Nor, finally, is it what climate science demands. Recall in particular the stark conclusion of renowned climate scientist Hansen and his colleagues in their analysis of the Paris Agreement's $2{ }^{\circ} \mathrm{C}$ target: "we have a global emergency. Fossil fuel $\mathrm{CO}_{2}$ emissions should be reduced as rapidly as practical." 312 Whereas Canadian climate policy appears to premised on the counterintuitive (and counterfactual) idea that it is possible to build new oil pipelines and mitigate GHG emissions at the same time. ${ }^{313}$ Or even more counterintuitive and

Quoted in Bruce Cheadle \& The Canadian Press, "Carr Tells Climate Forum Fossil Fuel Wealth Can't Be Left In the Ground," National Observer (21 October 2016), online: <https://www.national observer.com/2016/10/21/news/carr-tells-climate-forum-fossil-fuel-wealth-cant-be-left-ground> [emphasis added].

FL Morton, "The Constitutional Division of Powers with Respect to the Environment in Canada" in Kenneth M Holland, FL Morton \& Brian Galligan, eds, Federalism and the Environment: Environmental Policymaking in Australia, Canada, and the United States (Westport, Conn: Greenwood Press, 1996) 37 (arguing that "[a]s in all things Canadian, 'muddling through' is always a likely scenario" at 52).

See e.g. Amanda Harvey-Sanchez, "Opinion: Trudeau Could Lose Millennials (and the 2019 Election) if he Approves a Pipeline," National Observer (21 October 2016), online: $<$ https://www.national observer.com/2016/10/21/opinion/opinion-trudeau-could-lose-millennials-and-2019-election-if-heapproves-pipeline>.

Supra note 121.

RSC 1985, c F-14.

RSC 1985, c N-22.

Supra note 192. See also James Munson, "The AFN is Divided on Environmental Assessment Reform," (21 October 2017), online: <https://ipolitics.ca/2017/10/21/the-afn-is-divided-on-environmental-assess ment-reform/>.

310 James Munson, "The AFN is Divided on Environmental Assessment Reform," iPolitics (21 October 2017), online: $<$ https://ipolitics.ca/2017/10/21/the-afn-is-divided-on-environmental-assessmentreform/>.

311 Quoted in ibid.

312 Hansen et al, "Ice Melt, Sea Level Rise and Superstorms," supra note 78 at 3801.

313 MacLean, "The Misleading Promise of 'Balance,"” supra note 64. 
counterfactual still, that only by building new pipelines can we craft a pan-Canadian climate change mitigation policy. ${ }^{314}$ Let's talk climate contradiction?

The Trudeau government's approach to both federalism generally and climate change policymaking in particular appears to be more about empty formalism than actionable substance. Rather than federalism 3.0 - that is, bidirectional and responsive engagement with all Canadians, not just special interests, ${ }^{315}$ a new and collaborative partnership with provinces, territories, municipalities, and Indigenous peoples; and evidence-based policymaking — the government is practicing a kind of "check-the-box constitutionalism." 316 Establish formal consultations with Canadians, including Indigenous peoples — check. Form working groups with the provinces and the territories - check. Consider the direct and upstream GHG emissions of natural resources projects (while ignoring their cumulative effects on Canada's share of the global carbon budget tied to the global temperature targets established in the Paris Agreement) — check. Implement a price on carbon far below the true social cost of carbon pollution, with or without provincial and territorial consent - check. Proceed apace with large GHG-emitting natural resources projects that adversely impact traditional Indigenous rights and interests and make meeting our Paris Agreement commitments practically impossible - check. ${ }^{317}$ This is far removed from what Waldron, Gerken, Matsuda, and others view as the affirmative empowerment of constitutionalism and progressive federalism, whereby the state provides the housing and the furniture, as it were, required to facilitate responsible and transformative public deliberation. ${ }^{318}$ The Trudeau government's climate change policy is neither federalism 3.0 (or even a beta version thereof) nor a credible plan to meet Canada's commitments under the Paris Agreement.

For a critique of this argument on both economic efficiency and legal grounds, see Jason MacLean, "We Can't Build Pipelines and Meet Our Climate Goals," Maclean's (9 December 2016), online: $<$ www.macleans.ca/economy/economicanalysis/we-cant-build-pipelines-and-meet-our-climate-goals/> See also Jason MacLean, "Paris and Pipelines? Canada's Climate Policy Puzzle" (2018) J Envtl L \& Prac [forthcoming].

315 See e.g. Carol Linnitt, "Why is Trudeau Backtracking on B.C.'s Oil Tanker Ban? These 86 Meetings with Enbridge Might Help Explain," The Narwhal (21 October 2016), online: <https://www.the narwhal.ca/why-trudeau-back-tracking-b-c-s-oil-tanker-ban-these-86-meetings-enbridge-might-helpexplain $>$. It is beyond the scope of this article and, given the lack of complete data as of this writing, premature to explore the issue of lobbying and regulatory capture in respect of the current federal government's climate change policy. For an overview of this issue as the "root problem" of Canadian environmental law more generally, see Jason MacLean, "Striking at the Root Problem of Canadian Environmental Law: Identifying and Escaping Regulatory Capture" (2016) 29 J Envtl L \& Prac 111. See e.g. Jason MacLean, "Gateway to Nowhere: Environmental Assessment, the Duty to Consult, and the Social License to Operate in Gitxaala Nation v. Canada (Northern Gateway)" (July 2016) Toronto LJ 1 at 3.

317 See e.g. CS Mantyka-Pringle et al, "Honouring Indigenous Treaty Rights for Climate Justice" (2015) 5 Nature Climate Change 798 (arguing that "[t]ogether with other impacts, including those of hydroelectricity, roads and forestry, the rapid expansion of oil sands extraction (in addition to conventional oil and natural gas) can be viewed as a cumulative assault on the ecosystems of the Treaty Eight territory and the rights of the First Nations signatories of Treaty Eight" at 799).

318 Waldron, supra note 8 at 36. See also K Sabeel Rahman, Democracy Against Domination (New York: Oxford University Press, 2017). It is important to note, however, that federalism 3.0 does not contemplate - let alone require - any particular substantive outcome a priori (that is, a substantive pre-commitment to such-and-such a law or policy). As one anonymous peer reviewer objected in response to an earlier version of this article, "it is not self-evident to me that 'the Canadian people' generally would or could agree on any specific substantive laws. And that seems to be what federalism 3.0 requires." On the contrary, federalism 3.0, as I hope to have shown in this article, contemplates in terms that are unapologetically aspirational a procedural role for the state as the facilitator of meaningful democratic deliberation that is itself capable of producing substantive outcomes - laws and regulations - that Canadians can agree on, and short of the chimera of consensus, otherwise acknowledge as being democratically legitimate. Indeed, Canadians' lack of substantive agreement on a credible climate policy is not evidence of federalism 3.0's impossibility, but of its urgent need. 


\section{Conclusion: \\ The “Deliverology" of Paris, or Pipelines?}

The federal government's check-the-box constitutionalism and climate change policy appear to be a direct result of the government's subscription to the so-called science of "deliverology." 319 Developed by Sir Michael Barber, ${ }^{320}$ "deliverology" consists of a series of procedural protocols designed to help governments implement their policies. The Canadian government retained Barber's consultancy, Delivery Associates, in April 2016 to work with the Privy Council Office's "Results and Delivery Unit" - itself a product of deliverology speak s $^{321}$ - over a two-year period to provide ongoing information, recommendations and advice on a tailored program to guide departments to meet commitments and deliver on priorities. ${ }^{322}$

Deliverology is agnostic, however, about what it is that governments decide to deliver. Rule one of deliverology, for example, is to "HAVE AN AGENDA"; rule two is to "DECIDE ON YOUR PRIORITIES (really decide)." 323 Deliverology is not particularly bullish, however, on public consultation. In relaying his experience consulting on the reform of the school system in Pakistan, for example, Barber observes that "we could not have been more top-down if we had tried. 'Top-down' is often hurled as a term of abuse, but there are circumstances when it is the best approach." 324

Regarding the future development of "citizen engagement," wherein citizens "will expect to exercise choice as well as voice," 325 Barber is decidedly circumspect. Responding to commentators who argue that the new "open, participatory and peer-driven" power of public participation is poised to replace the older model of "closed, inaccessible and leader-driven" power, Barber is unmoved: "I doubt that new power will replace old power." 326

Canadians had better hope that Barber is wrong. So far, the government's promise of "real change" is far more federalism 2.0 than 3.0, far more NP2 than NP3. As Harrison astutely noted in respect of climate federalism 2.0, "for two decades Canadian politicians have embraced the 'sustainable development' mantra that economic prosperity and environmental protection go hand in hand: Canada can save the planet and get rich too." ${ }^{227}$ Fast-forward to Prime Minister Trudeau's first speech from the throne, wherein he promised that his "Government will prove to Canadians and to the world that a clean environment and a strong

Michelle Zilio, "Liberals Spend \$200,000 for Advice on Delivering Campaign Pledges," The Globe and Mail (30 September 2016), online: <https://www.theglobeandmail.com/news/politics/liberals-spend200000-for-advice-on-delivering-campaign-pledges/article32187629/> [Zilio, "Advice on Delivering Campaign Pledges"].

See e.g. Michael Barber, How to Run a Government: So That Citizens Benefit and Taxpayers Don't Go Crazy (UK: Allen Lane, 2015). Barber sets out 57 rules of delivery (ibid at 291-94).

Ibid (Rule 10: "SET UP A DELIVERY UNIT (call it what you like, but separate it from strategy and policy)" at 291).

Zilio, “Advice on Delivering Campaign Pledges," supra note 319.

Barber, supra note 320 at 291.

Ibid at 22.

Ibid at 284 .

Ibid.

Harrison, "Challenges and Opportunities," supra note 97 at 341. 
economy go hand in hand. We cannot have one without the other." ${ }^{328}$ More to the point, Canada's Minister of the Environment and Climate Change, Catherine McKenna, who describes herself as being "as much an economic minister as I am an environment minister," ${ }^{329}$ launched the government's review of its environmental assessment processes by reiterating "[o]ur belief that a clean environment and a strong economy go hand in hand is central to the health and well-being of Canadians. This is especially important as we work to get resources to market and develop major projects responsibly in the twenty-first century. Canadians expect and deserve to have an environmental assessment system that they can trust." ${ }^{330}$ Deliverology Rule 49: "DRIFT IS THE ENEMY OF DELIVERY (momentum is its friend). ${ }^{, 331}$

To whom, then, does the power to change the world belong? It is still too early to say for certain. However, notwithstanding the aspirations of federalism 3.0 and the Paris Agreement, the odds in Canada appear to favour the denizens of conference rooms over those in the streets, be they the streets of Paris or Ottawa. ${ }^{332}$ Instead of democracy, there will be "Deliverology"; in lieu of Paris, pipelines. ${ }^{333}$ For both our constitution and our climate, the harm may well be irreparable. ${ }^{334}$

Government of Canada, "Making Real Change Happen: Speech From the Throne to Open the First Session of the Forty-second Parliament of Canada," online: <speech.gc.ca/en/content/making-realchange-happen $>$.

Bruce Cheadle \& The Canadian Press, supra note 302.

330 Government of Canada, News Release, "Government of Canada Moving Forward with Environmental Assessment Review"(15 August 2016), online: <https://www.canada.ca/en/environmental-assessmentagency/news/2016/08/government-of-canada-moving-forward-with-environmental-assessmentreview.html>.

Barber, supra note 320 at 294.

Solnit, supra note 1.

In an apt afterword to this article, as of this writing, even as the Federal Court of Appeal's decision in the consolidated judicial review of the federal government's approval of the Trans Mountain pipeline expansion remains pending, the federal government has purchased the project outright from the proponent, Kinder Morgan. See Steven Chase, Kelly Cryderman \& Jeff Lewis, "Trudeau Government to Buy Kinder Morgan's Trans Mountain for \$4.5-Billion,” The Globe and Mail (29 May 2018), online: $<\mathrm{https} / / / \mathrm{www}$.theglobeandmail.com/politics/article-trudeau-government-to-buy-kinder-morgans-transmountain-pipeline/>.

334 This is hardly hyperbole. The federal government's purchase and nationalization of the Trans Mountain pipeline project over the opposition of Indigenous groups, climate scientists, environmental law and policy scholars, environmental advocates, the municipalities of Burnaby and Vancouver, and the provinces of British Columbia and Quebec prompted Homer-Dixon and Strauch to seriously speculate about whether Canada might become "the first country to break apart over the issue of climate change" (Thomas Homer-Dixon \& Yonatan Strauch, "The Great Canadian Climate Delusion," The Globe and Mail (1 June 2018), online: $<$ https://www.theglobeandmail.com/opinion/article-is-canada-going-to-bethe-first-country-to-break-apart-over-climate/>). 